\title{
Demersal Assemblages on the Soft Bottoms off the Catalan-Levante Coast of the Spanish Mediterranean
}

\author{
Mariano García-Rodríguez,, ${ }^{1}$ Pere Abelló, ${ }^{2}$ Angel Fernández, ${ }^{3}$ and Antonio Esteban ${ }^{3}$ \\ ${ }^{1}$ Instituto Español de Oceanografía, Servicios Centrales, Corazón de María 8, 28002 Madrid, Spain \\ ${ }^{2}$ Institut de Ciències del Mar (CSIC), Passeig Marítim 37-49, 08003 Barcelona, Spain \\ ${ }^{3}$ Instituto Español de Oceanografía, Centro Oceanográfico de Murcia, C/ Varadero 1, San Pedro del Pinatar, 30740 Murcia, Spain
}

Correspondence should be addressed to Mariano García-Rodríguez, mariano.garcia@md.ieo.es

Received 12 May 2011; Revised 11 August 2011; Accepted 12 September 2011

Academic Editor: Jakov Dulčić

Copyright ( $\odot 2011$ Mariano García-Rodríguez et al. This is an open access article distributed under the Creative Commons Attribution License, which permits unrestricted use, distribution, and reproduction in any medium, provided the original work is properly cited.

\begin{abstract}
The analysis of 255 bottom trawl samples obtained in annual experimental surveys (2007-2010) along the western Mediterranean shows the existence of five well-defined demersal assemblages that follow a depth distribution: (a) upper shelf assemblages, including two assemblages differentiated by the type of substrate (sand-muddy and terrigenous muddy bottoms); (b) a middle shelf assemblage; (c) an upper slope assemblage; (d) a middle slope assemblage. Faunally, they are dominated by fish (37\% of 452 total species), followed by crustaceans (22\%), molluscs (17\%), echinoderms (9\%), and other invertebrates (15\%). The assemblages identified showed major alterations on the shelf and shelf edge and less pronounced ones on the upper and middle slope. The average diversity values were more or less high, evidencing the high species richness in the western Mediterranean. The identified assemblages may facilitate future multispecies fisheries management based on an ecosystem approach.
\end{abstract}

\section{Introduction}

An assemblage is a group of species whose distribution in space and time overlaps in a certain area, sharing a same habitat, bathymetric range, and so forth. A species assemblage describes the collection of species making up any cooccurring community of organisms in a given habitat or fishing ground. Often, these assemblages are also called communities. In biological terms, a community is a group of interacting organisms sharing a populated environment. In the case of the demersal species, species that dwell at or near the bottom interacting among them according to their behaviour, the identification of these assemblages according to species composition, spatial distribution, and stability will allow to determine the degree of incidence of the impacts of anthropic origin, specially trawl fishing, on them.

The impacts of fishing on ecosystems are diverse in nature [1-3]. Trawling cannot only cause damage to physical components of the habitats, and therefore implying a reduction in biodiversity, but also changes the community structure, species abundance, and their size structure. In summary, it can be said that in addition to the physical alteration of habitats, fishing causes a reduction in population size of both target and nontarget species, alters their demographic structure, and substantially modifies the structure and composition of communities [4-8]. Communities less impacted by trawling sustain more biogenically habitatstructured communities (e.g., more abundance of sessile suspension feeders at the less disturbed sites versus higher dominance of small invertebrates at the disturbed site) [9].

Consequently, the knowledge of the different communities inhabiting the trawled bottoms is fundamental to understand the dynamics of communities and populations and their relationships with the structure of the habitats and environmental factors, as well as the fishing impacts on them.

Demersal fish communities and the depth distribution of their component species have been studied in various areas of the Mediterranean Sea, such as the Tyrrhenian Sea [10], the Ionian Sea [11], the Aegean Sea [12, 13], the Adriatic Sea [14], and the Gulf of Lions [15]. The studies referring to demersal fish communities in the Spanish Mediterranean include those of the Balearic Islands [16-18], on the shelf 


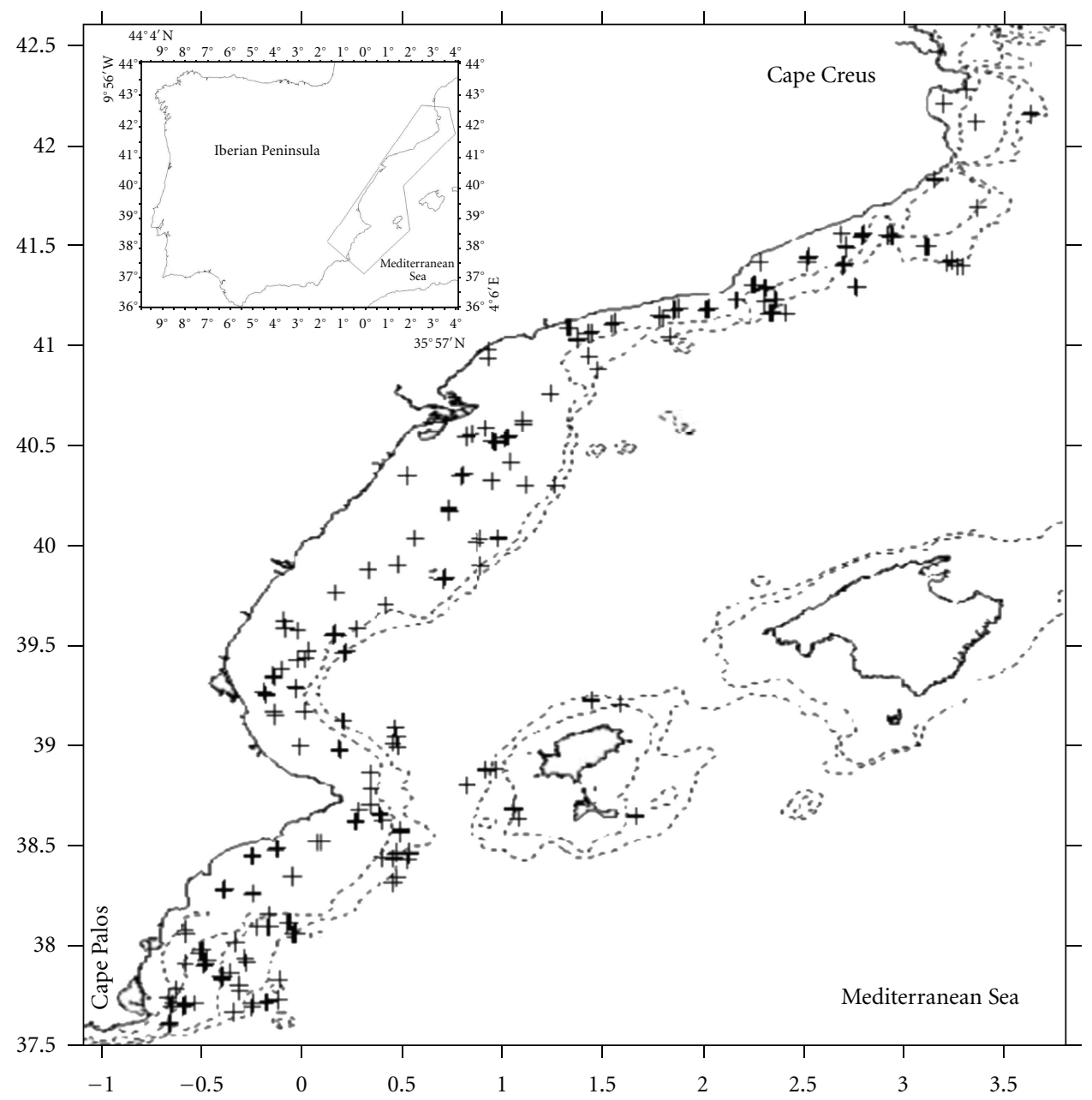

FIGURE 1: Location of study area and sampling points. Cumulative data from MEDITS surveys series for the period 2007-2010.

and slope of Catalonia [19, 20], in the Alboran Sea [21] and in the Gulf of Alicante [22]. The species that inhabit deep zones, below $1000 \mathrm{~m}$, have been studied in the Catalan Sea [23]. Crustacean communities have been studied in the Catalan Sea [24-26], elasmobranch communities in the Balearic Islands [27], and cephalopod communities both in the Balearic Islands [28] and on the Mediterranean coast of the Spanish mainland [29], while the relationships between macro-epibenthic communities and fish were studied in the Balearic Islands [30].

On the other hand, fisheries must be managed not only to optimize catches, but to attain sustainability of the resources and ecosystems. In this sense, the traditional approach, based on single stock assessment, represents an inadequate management strategy for multispecies fisheries [31]. The integrated assessment of fisheries requires studies that focus on the ecosystem as a whole rather than on a single species, and that considers fishing activities as key pressures affecting various components of the ecosystem. In this sense, the use of an ecosystem approach to fisheries management (EAFM) may provide a holistic view of the ecosystem-fisheries interactions, while trophic indicators could therefore be used to support the implementation of an EAFM by providing information on the state of the ecosystem [32].

However, studies dealing on demersal assemblages as a whole, that is, not limited to a specific community or taxocenosis but considering all the species, including fish, crustaceans, cephalopods, and other invertebrates, and thus encompassing the relationships between macro-epibenthic invertebrates and demersal fish are scarce in the western Mediterranean [33-35] as well as on the Spanish coast [30, $36,37]$.

In the Spanish Mediterranean, the total trawl fleet in 2009 was composed by 797 vessels [38]. It operates mainly in local fishing grounds, although a limited number of vessels work in French waters of the Gulf of Lions. The fleet can be divided into three groups: vessels that operate on the continental shelf (shelf trawlers), vessels that operate at the shelf edge and the beginning of the continental slope (slope trawlers), and vessels that fish in deeper areas of the slope (bottom trawlers). While trawl catches in the Mediterranean are multispecific [39], each of the above groups of vessels targets on specific faunistic groups of commercial interest [40]. The main part of landings consists of small individuals that have been recently recruited to the fishery [41]. It was 
TABLE 1: Distribution of the number of hauls per depth stratum for each year of study. MEDITS surveys series 2007-2010.

\begin{tabular}{lccccc}
\hline Strata/Year & 2007 & 2008 & 2009 & 2010 & Total \\
\hline $0-50$ & 5 & 7 & 4 & 5 & 21 \\
$50-100$ & 26 & 29 & 14 & 19 & 88 \\
$100-200$ & 15 & 20 & 13 & 12 & 60 \\
$200-500$ & 13 & 14 & 13 & 10 & 50 \\
$500-800$ & 10 & 11 & 8 & 7 & 36 \\
\hline Total & 69 & 81 & 52 & 53 & 255 \\
\hline
\end{tabular}

therefore expected that the demersal communities in the area would have undergone changes caused by the intense and prolonged trawl fishing.

In the Spanish Mediterranean two biogeographical areas separated by Cape Palos can be clearly distinguished: the Alboran Sea to the south of the Cape and the LevanteCatalonia area to the northeast [26] and adding a third one to the north: the Gulf of Lions in the French Mediterranean [15]. The intermediate area between Cape Palos and the Gulf of Lions was selected as the study area and is equivalent to the Geographical Subarea 6 established by the General Fisheries Commission for the Mediterranean (GFCM).

The selected area is subjected to high fishing intensity exerted mainly by trawling fleets. In 2009 the trawl fleet in this area consisted of 603 vessels, according to the statistics of the Autonomous Governments of Valence (305 in southern GSA06) and Catalonia (298 in northern GSA 06). Some of these units (smaller vessels) operate almost exclusively on the continental shelf targeting red mullet, octopus, hake, and sea breams, while others (bigger vessels) operate almost exclusively on the continental slope targeting shrimps and Norway lobster, and the rest can operate indistinctly on the continental shelf and slope fishing grounds, depending on the season, the weather conditions, and also economic factors (e.g., landings price). The percentages of these trawl fleet segments have been estimated around 30,40 and 30\% of the boats, respectively [42]. The management of this fishery is based on effort control, with limitations placed on the number of boats, their nominal engine power (maximum of $500 \mathrm{hp}$ ) and the maximum time at sea (5 days per week and $12 \mathrm{~h}$ per day), and other technical measures such as prohibiting operation on bottoms shallower than $50 \mathrm{~m}$, and in some marine protected areas. In the last years, a diminishing trend in the number of vessels that work in the area was noted. However, the high fishing intensity over a long period of time could lead to structural changes in the demersal assemblages in the area.

In this sense, we set out to perform the present study to characterize the demersal assemblages in the area, identifying their specific composition, structure and distribution, analyzing their diversity, and determining their possible alterations, thus aiming to provide a basis for future studies.

\section{Materials and Methods}

The study area includes soft bottoms located between Cape Palos and Cape Creus along the Catalan-Levante front of the
Spanish Mediterranean (FAO-GFCM Geographical Subarea 6) (Figure 1). The samples were collected in successive demersal trawl surveys performed in spring between 2007 and 2010, following the standard international MEDITS series methodology [43]. The main objective of the programme was to obtain independent knowledge useful for the fishery management, in an area where it is difficult to follow in detail the exploitation patterns of the fishing fleets [44]. The fishing gear used was a GOC bottom trawl with an opening of $17.5 \mathrm{~m}$ wide and $2.5 \mathrm{~m}$ high from the bottom and $20 \mathrm{~mm}$ mesh at the cod end. This gear was object of some specific studies to complete the knowledge about the efficiency of the gear when compared with commercial ones [45] as well as with both experimental and commercial gears [46]. The sampling gear and its handling have been slightly modified to improve its performance, especially to better stabilize it when contacting the bottom [44]. A stratified random sampling design was used, considering five depth strata $(0-50 \mathrm{~m}, 50-100 \mathrm{~m}, 100-200 \mathrm{~m}, 200-500 \mathrm{~m}$, and 500$800 \mathrm{~m}$ ) sampled with intensity proportional to their areas [47]. The gear geometry was controlled by a SCANMAR system and, parallel to the trawl, a CTD SBE-37 probe placed at the mouth of the net provided in situ data on depth, temperature, and salinity. The trawls had a duration of $30 \mathrm{~min}$ on bottoms shallower than $200 \mathrm{~m}$ depth and $60 \mathrm{~min}$ on bottoms deeper than $200 \mathrm{~m}$. After the sample had been processed, the data were fed into a computer database, which calculated the values of abundance and biomass per swept area, expressed in individuals and kilograms per square kilometre, respectively.

In this study, we considered a total of 255 samples, distributed in different years and depth strata, as described in Table 1. The data were used to construct abundance and biomass files for the species found in each haul and for the controlled variables. Similarity matrices were calculated using the Bray-Curtis index, with square root transformation, and a cluster analysis was performed on the rank similarities. We then performed multidimensional scaling (MDS) to observe the ordination of the samples, superimposing the depth variable. Once the groups had been established, the null hypothesis (no differences in the assemblages of the various groups) was contrasted using analysis of similarity (ANOSIM) (one-way ANOVA test).

On the identified groups we analyzed the contribution of species to similarity using similarity percentages (SIMPER), assessing the importance of species in each group and making comparisons between them. Then, we plotted the 


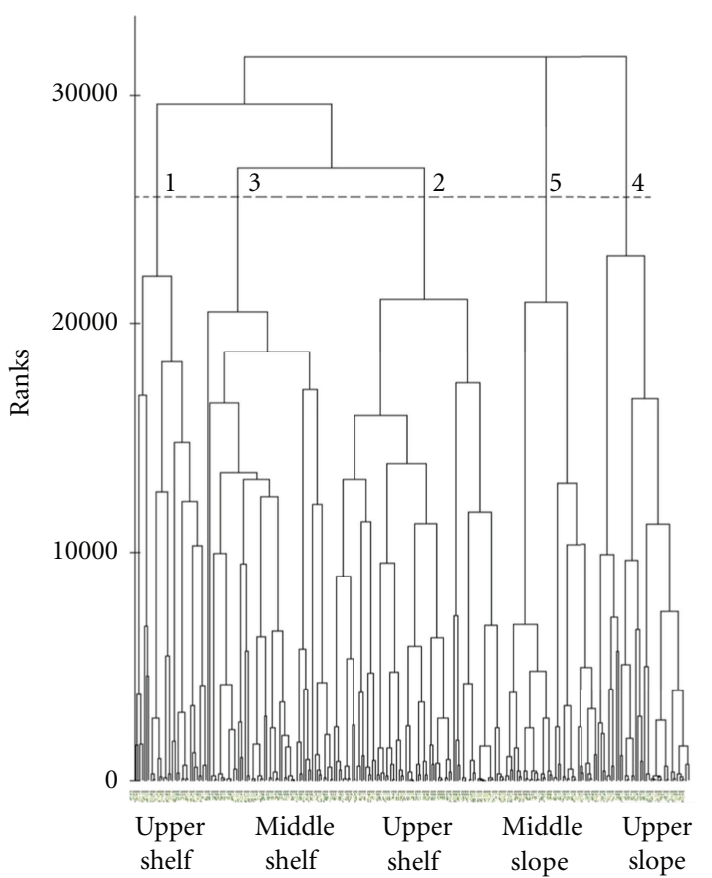

(a)

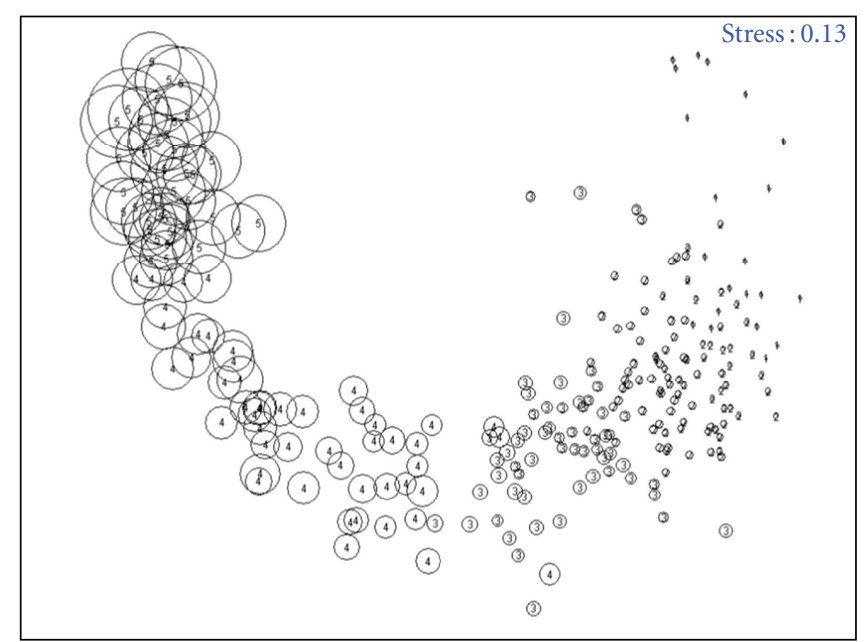

(b)

FIGURE 2: (a) Dendrogram of similarities between samples, showing the identified groups. U.Sh.: upper shelf; M.Sh.: middle shelf; U.Sl.: upper slope; M.Sl.: middle slope. (b) Multidimensional scaling (MDS) of the samples with identification of the group to which they belong. The volume of the bubble is proportional to the depth in metres. Data from MEDITS surveys series 2007-2010.

abundance biomass comparison curves for each group identified, evaluating the alteration of each assemblage in function of the dominance of each variable, obtaining in addition the distributions of species abundances. The $k$ dominance curves of abundance-biomass are an ordination of the cumulative percentage contribution of the species importance in terms of abundance and biomass, compared with each other. Finally, data on biodiversity measures (DIVERSE) were obtained for the selected groups. Average abundance $(N)$, number of species $(S)$, species richness $(D)$ (Margalef index), Pielou evenness $(J)$, and Shannon-Wiener diversity (Hloge) were calculated for each group of samples. Correlation between abiotic factors and diversity indices was checked by means of Pearson's correlation coefficient. Diversity indices of each assemblage were checked for differences in mean by year (ANOVA). Diversity indices are measures of richness (the number of species in a system); to some extent, evenness (variances of species' local abundance). All tests were performed using the corresponding subroutines of the PRIMER program [48].

\section{Results}

A total of 452 species were identified in the sampling period. Fish showed the largest number $(167 ; 36.9 \%)$, followed by crustaceans $(99 ; 21.9 \%)$, molluscs $(75 ; 16.6 \%)$, echinoderms (42; 9.3\%), and other groups such as ascidians (22; 4.9\%), cnidarians $(22 ; 4.9 \%)$, polychaetes $(4 ; 0.9 \%)$, and others $(21$; $4.6 \%)$. The species with the largest overall mean abundances considering all samples were the fish Micromesistius poutas- sou (Risso, 1826), Glossanodon leioglosus (Valenciennes, 1848), Engraulis encrasicolus (Linnaeus, 1758), Gadiculus argenteus (Guichenot, 1850), Sardina pilchardus (Walbaum, 1792), Aphia minuta (Risso, 1810), Trachurus trachurus (Linnaeus, 1758), Spicara maena (Linnaeus, 1758), and Capros aper (Linnaeus, 1758); the crustaceans Plesionika heterocarpus (Costa, 1871), Pasiphaea sivado (Risso, 1816), Aristeus antennatus (Risso, 1816), and the cephalopod Alloteuthis media (Linnaeus, 1758). Algae of the families Corallinaceae and Rodophiceae also showed high abundances in some specific hauls (maërl bottoms) on the upper shelf. Merluccius merluccius (Linnaeus, 1758) was the species found in most samples, with a frequency of occurrence of $90 \%$, followed by T. trachurus, Boops boops (Linnaeus, 1758), C. aper, and Mullus barbatus (Linnaeus, 1758), with a frequency of $60 \%$. The cephalopods Illex coindetii (Vérany, 1839), A. media, and Eledone cirrhosa (Lamarck, 1798), the crustacean Liocarcinus depurator (Linnaeus, 1758), and the echinoderm Astropecten irregularis (Linck, 1733) also had a frequency of occurrence higher than $60 \%$.

Cluster analysis clearly separated five main groups. At a similarity level greater than $10 \%$ or a rank value of 25,000 , five groups were clearly identified (Figure 2(a)). The results of the MDS show depth-dependent groups consistent with those defined by cluster analysis (Figure 2(b)). Consequently, the groups were numbered consecutively according to their mean depth. The results of the ANOSIM test for differences between groups of samples confirmed the differences established by cluster analysis and MDS in all cases (global $R=$ $0.802 ; P<0.1)$. In addition, the results of mean similarities 
TABLE 2: Characteristics of the identified groups; number of hauls considered in each group $(N)$, mean similarity values of each group, and mean dissimilarity values between groups. Data from MEDITS surveys series 2007-2010.

\begin{tabular}{lccccc}
\hline Group & 1 & 2 & 3 & 4 & 5 \\
\hline$N$ & 33 & 79 & 58 & 42 & 43 \\
Similarity & 29.99 & 36.49 & 35.99 & 35.23 & 40.58 \\
\hline \multicolumn{5}{c}{ Dissimilarity } \\
1 & - & & & \\
2 & 74.52 & - & & & \\
3 & 79.87 & 73.35 & - & - & - \\
4 & 92.24 & 91.76 & 81.61 & 85.35 & \\
5 & 98.22 & 98.42 & 95.83 & & \\
\hline
\end{tabular}

and dissimilarities between groups (Table 2) supported the validity of the separation of the groups.

The groups identified in the cluster (Figure 2) were related to the upper shelf (U.Sh., Groups 1 and 2), the middle shelf (M.Sh., Group 3), the upper slope (U.Sl., Group 4), and the middle slope (M.Sl., Group 5). The SIMPER analysis (Table 3) showed that the upper shelf assemblages (mean depth $70 \mathrm{~m}$ ) were characterized by the presence of the fishes S. pilchardus, E. encrasicolus, Spicara flexuosa (Rafinesque, 1810), Spicara smaris (Linnaeus, 1758), B. boops, T. trachurus, A. minuta, M. merluccius, and Trisopterus minutus (Linnaeus, 1758); the cephalopods A. media, I. coindetii, and Octopus vulgaris (Cuvier, 1797); the crustaceans Pagurus prideaux (Leach, 1815), L. depurator and Dardanus arrosor (Herbst, 1776); and the echinoderms Stichopus regalis (Cuvier, 1817), Echinaster sepositus (Retzius, 1783), and A. irregularis. On the middle shelf (mean depth $128 \mathrm{~m}$ ) we observed a dominance of the bony fish M. merluccius, T. trachurus, C. aper, T. minutus, M. poutassou, and M. barbatus, and the elasmobranch fish Scyliorhynus canicula (Linnaeus, 1758); the cephalopods A. media, I. coindetii and E. cirrhosa; the crustaceans $L$. depurator and Macropodia longipes (A. Milne-Edwards and Bouvier, 1899); and the echinoderms A. irregularis and $S$. regalis. At the upper slope (mean depth $298 \mathrm{~m}$ ) the dominant species were the fish G. argenteus, M. poutassou, Phycis blennoides (Brünnich, 1768), S. canicula, and Helicolenus dactylopterus (Delaroche, 1809); the crustaceans P. heterocarpus, M. tuberculatus, and Nephrops norvegicus (Linnaeus, 1758); the cephalopods Sepietta oweniana (d'Orbigny, 1840), and E. cirrhosa. On the middle slope (mean depth $589 \mathrm{~m}$ ), the dominant species were the fish Lampanictus crocodilus (Risso, 1810), Galeus melastomus (Rafinesque, 1810), and P. blennoides and crustaceans such as Plesionika martia (A. Milne-Edwards, 1883), A. antennatus, Polycheles typhlops (Heller, 1862), N. norvegicus, and Pasiphaea multidentata (Lesmark, 1866). The cephalopods were represented by Todarodes sagittatus (Lamarck, 1798).

Some of these species made a considerable contribution to establishing the dissimilarity between the selected assemblages (Table 4). On the upper shelf, the species that marked the difference between the selected assemblages were $S$. flexuosa, B. boops, M. barbatus, Pagellus erythrinus (Linnaeus, 1758), and S. smaris, which were far more abundant in Group 1 meanwhile S. pilchardus, E. encrasicolus, A. media, and
M. merluccius dominated in the Group 2. On the upper shelf and middle shelf the differences between assemblages were based on the abundances of C. aper, M. poutassou, T. trachurus, M. merluccius and T. minutus, which were far greater on the middle shelf. The differences between the middle shelf and that of the upper slope were based on the abundances of $G$. argenteus, P. heterocarpus, P. blennoides, $P$. sivado, and S. canicula. Finally, the middle slope showed greater abundances of $L$. crocodilus, A. antennatus, and $P$. martia than the upper slope.

The number of species found varied slightly between the assemblages. On the upper shelf the mean number of species per sample varied between 47 and 37 according to the group considered. On the middle shelf, the mean number was very similar to the lowest value of the upper shelf (37). The mean number of species found on the upper slope was higher than that on the middle slope, at 42 and 37, respectively (Table 5; Figure 6). Mean diversity values were moderate, being lower on the middle shelf and on the upper slope. The different biological diversity indices per sample varied between the groups, yielding moderate values, around the mean value of the range in each index (Table 5). In general, the variations in diversity with depth and the decrease in abundance were not significant (Table 6).

The year of sampling and the latitude at which the samples were obtained showed no significant correlations with other variables and diversity indices considered, except the correlation of year with temperature, that was negative and significant (Table 6). Temperature showed a significant decrease along the sampling period, meaning that the average temperature of the samples decreased over the period. The other abiotic variables monitored showed a high correlation with each other. Depth was negatively correlated with temperature, decreasing with increasing depth, and was positively correlated with salinity that increased with depth. Temperature and salinity were also negatively correlated, with temperature decreasing with increasing salinity (Figure 3). Diversity indices showed positive and significant correlations between them; when considering year as a factor, differences in mean values of diversity indices were not significant $(P>0.05)$, suggesting that diversity indices remained stable along the sampling period.

In addition to being depth dependent, the assemblages identified followed a pattern with respect to temperature 
TABLE 3: Species contribution to similarity in each of the six groups resulting from the cluster analysis. ABU: mean abundance in the cluster group $\left(\mathrm{n} / \mathrm{km}^{2}\right)$; \% Cum: cumulative percentage of species contribution. Data from MEDITS surveys series 2007-2010.

\begin{tabular}{|c|c|c|}
\hline Species & $\mathrm{ABU}$ & \% Cum. \\
\hline \multicolumn{3}{|c|}{ Group 1} \\
\hline Spicara flexuosa & 3626.31 & 11.89 \\
\hline Boops boops & 3348.89 & 22.51 \\
\hline Trachurus trachurus & 2688.24 & 28.85 \\
\hline Mullus barbatus & 1557.57 & 34.46 \\
\hline Merluccius merluccius & 994.31 & 40.06 \\
\hline Pagellus erythrinus & 1371.72 & 44.23 \\
\hline Trachurus mediterraneus & 1784.88 & 48.39 \\
\hline Serranus hepatus & 197.87 & 51.84 \\
\hline Spicara smaris & 3573.98 & 55.11 \\
\hline Dardanus arrosor & 367.91 & 57.91 \\
\hline Pagellus acarne & 776.22 & 60.54 \\
\hline Octopus vulgaris & 144.28 & 62.86 \\
\hline Illex coindetii & 153.82 & 64.83 \\
\hline Alloteuthis media & 378.79 & 66.66 \\
\hline Scyliorhinus canicula & 476.48 & 68.35 \\
\hline Eledone cirrhosa & 82.92 & 69.87 \\
\hline Arnoglosus thori & 193.19 & 71.36 \\
\hline Sardina pilchardus & 592.19 & 72.77 \\
\hline Lepidotrigla cavillone & 173.84 & 74.18 \\
\hline Mullus surmuletus & 236.7 & 75.48 \\
\hline Lophius budegassa & 50.61 & 76.67 \\
\hline Stichopus regalis & 227.71 & 77.76 \\
\hline Phallusia mamillata & 343.16 & 78.81 \\
\hline Trachinus draco & 58.21 & 79.77 \\
\hline Ascidiidae & 122.58 & 80.63 \\
\hline Trisopterus minutus & 2041.41 & 81.43 \\
\hline Serranus cabrilla & 259.17 & 82.15 \\
\hline Alcyonium palmatum & 193.55 & 82.85 \\
\hline Echinaster sepositus & 211.06 & 83.48 \\
\hline Diplodus vulgaris & 121.44 & 84.08 \\
\hline Astropecten irregularis & 24.22 & 84.68 \\
\hline Chelidonichthys lastoviza & 708 & 85.27 \\
\hline Deltentosteus quadrimaculatus & 57.01 & 85.84 \\
\hline Macropodia tenuirrostris & 26.41 & 86.39 \\
\hline Ascidia mentula & 138.17 & 86.9 \\
\hline Diplodus annularis & 603.73 & 87.4 \\
\hline Pilumnus spinifer & 28.9 & 87.89 \\
\hline Zeus faber & 28.48 & 88.83 \\
\hline Sepia officinalis & 32.38 & 89.22 \\
\hline Polycarpa pomaria & 220.38 & 89.61 \\
\hline Pagurus prideaux & 454.61 & 89.99 \\
\hline Microcosmus vulgaris & 164.18 & 90.38 \\
\hline \multicolumn{3}{|c|}{ Group 2} \\
\hline Alloteuthis media & 2176.04 & 12.93 \\
\hline Merluccius merluccius & 2275.56 & 24.86 \\
\hline
\end{tabular}

TABLE 3: Continued.

\begin{tabular}{|c|c|c|}
\hline Species & $\mathrm{ABU}$ & \% Cum. \\
\hline Trachurus trachurus & 3332.84 & 35.71 \\
\hline Sardina pilchardus & 7538.3 & 44.37 \\
\hline Boops boops & 862.9 & 51.25 \\
\hline Engraulis encrasicolus & 7485.65 & 56.95 \\
\hline Trachurus mediterraneus & 1037.77 & 61.19 \\
\hline Serranus hepatus & 306.58 & 64.06 \\
\hline Trisopterus minutus & 1201.81 & 66.83 \\
\hline Liocarcinus depurator & 387.74 & 69.23 \\
\hline Mullus barbatus & 586.49 & 71.27 \\
\hline Illex coindetii & 504.08 & 73.23 \\
\hline Cepola macrophthalma & 337.53 & 75.19 \\
\hline Pagellus erythrinus & 318 & 77.13 \\
\hline Spicara flexuosa & 267.45 & 78.87 \\
\hline Aphia minuta & 2989.04 & 80.51 \\
\hline Lepidotrigla cavillone & 231.78 & 82.01 \\
\hline Astropecten irregularis & 140.35 & 83.28 \\
\hline Spicara smaris & 81.39 & 84.3 \\
\hline Capros aper & 310.28 & 85.12 \\
\hline Diplodus annularis & 701.53 & 85.94 \\
\hline Arnoglosus laterna & 86.93 & 86.67 \\
\hline Alloteuthis subulata & 66.94 & 87.39 \\
\hline Scomber scombrus & 198.69 & 88.06 \\
\hline Citharus linguatula & 56.28 & 88.59 \\
\hline Eledone cirrhosa & 42.71 & 89.1 \\
\hline Pelagia noctiluca & 93.73 & 89.6 \\
\hline Octopus vulgaris & 23.31 & 90.07 \\
\hline \multicolumn{3}{|c|}{ Group 3} \\
\hline Merluccius merluccius & 4300.94 & 16.56 \\
\hline Trachurus trachurus & 8477.77 & 32.71 \\
\hline Capros aper & 6602.24 & 47.03 \\
\hline Trisopterus minutus & 2046.07 & 54.15 \\
\hline Alloteuthis media & 1264.22 & 59.75 \\
\hline Micromessistius poutassou & 36083.68 & 63.86 \\
\hline Illex coindetii & 334.25 & 67.76 \\
\hline Mullus barbatus & 371.4 & 71.15 \\
\hline Scyliorhinus canicula & 550.15 & 73.22 \\
\hline Eledone cirrhosa & 109.25 & 74.89 \\
\hline Lophius budegassa & 62.48 & 76.32 \\
\hline Lepidotrigla cavillone & 114.92 & 77.68 \\
\hline Cepola macrophthalma & 130.62 & 78.81 \\
\hline Liocarcinus depurator & 111.18 & 79.94 \\
\hline Macroramphosus scolopax & 103.67 & 81.07 \\
\hline Astropecten irregularis & 1328.26 & 82.19 \\
\hline Boops boops & 120.17 & 83.31 \\
\hline Serranus hepatus & 84.34 & 84.21 \\
\hline Zeus faber & 29.18 & 85.12 \\
\hline Sepia orbignyana & 51.24 & 85.97 \\
\hline Macropodia tenuirrostris & 55.58 & 86.66 \\
\hline Plesionika heterocarpus & 1207.52 & 87.29 \\
\hline
\end{tabular}


TABle 3: Continued.

\begin{tabular}{|c|c|c|}
\hline Species & $\mathrm{ABU}$ & $\%$ Cum. \\
\hline Stichopus regalis & 112.14 & 87.91 \\
\hline Pelagia noctiluca & 556.11 & 88.51 \\
\hline Helicolenus dactylopterus & 221.1 & 89.08 \\
\hline Lepidorhombus boscii & 40.65 & 89.66 \\
\hline Phycis blennoides & 39.08 & 90.18 \\
\hline \multicolumn{3}{|c|}{ Group 4} \\
\hline Gadiculus argenteus & 10603.1 & 15.94 \\
\hline Micromessistius poutassou & 8774.87 & 27.68 \\
\hline Plesionika heterocarpus & 3418.14 & 36.08 \\
\hline Phycis blennoides & 1312.92 & 43.2 \\
\hline Scyliorhinus canicula & 1000.87 & 48.9 \\
\hline Macropipus tuberculatus & 327.67 & 52.8 \\
\hline Helicolenus dactylopterus & 636.33 & 56.23 \\
\hline Capros aper & 831.78 & 59.06 \\
\hline Nephrops norvegicus & 528.09 & 61.83 \\
\hline Merluccius merluccius & 309.44 & 64.18 \\
\hline Sepietta oweniana & 273.6 & 66.41 \\
\hline Plesionika giglioli & 401.14 & 68.52 \\
\hline Pasiphaea sivado & 2501.06 & 70.51 \\
\hline Eledone cirrhosa & 66.44 & 72.24 \\
\hline Solenocera membranacea & 247.04 & 73.93 \\
\hline Parapenaeus longirostris & 180.84 & 75.41 \\
\hline Munida intermedia & 214.37 & 76.84 \\
\hline Trachurus trachurus & 542.87 & 78.14 \\
\hline Lepidorhombus boscii & 80.13 & 79.43 \\
\hline Lophius budegassa & 62.1 & 80.59 \\
\hline Lepidopus caudatus & 1622.65 & 81.66 \\
\hline Coelorinchus caelorhincus & 354.65 & 82.63 \\
\hline Liocarcinus depurator & 239.34 & 83.58 \\
\hline Maurolicus muelleri & 204.83 & 84.34 \\
\hline Chlorotocus crassicornis & 76.23 & 85.04 \\
\hline Trigla lyra & 75.11 & 85.73 \\
\hline Illex coindetii & 47.38 & 86.39 \\
\hline Munida rutllanti & 93.73 & 87.01 \\
\hline Chlorophtalmus agasizii & 103.72 & 87.59 \\
\hline Dardanus arrosor & 17.27 & 88.14 \\
\hline Octopus salutii & 29.08 & 88.68 \\
\hline Alpheus glaber & 80.41 & 89.2 \\
\hline Pagellus bogaraveo & 41.64 & 89.69 \\
\hline Lampanictus crocodrilus & 184.39 & 90.17 \\
\hline \multicolumn{3}{|c|}{ Group 5} \\
\hline Lampanictus crocodrilus & 1196.54 & 14.19 \\
\hline Galeus melastomus & 446.57 & 21.88 \\
\hline Plesionika martia & 626.62 & 29.34 \\
\hline Phycis blennoides & 251.77 & 36.41 \\
\hline Aristeus antennatus & 560.6 & 43.16 \\
\hline Polycheles typhlops & 124.42 & 48.21 \\
\hline Nephrops norvegicus & 391.85 & 53.09 \\
\hline Pasiphaea multidentata & 141.45 & 57.72 \\
\hline
\end{tabular}

TABle 3: Continued.

\begin{tabular}{lcc}
\hline Species & ABU & $\%$ Cum. \\
\hline Sergia robusta & 87.06 & 60.75 \\
Nezumia aequalis & 148.06 & 63.54 \\
Plesionika acanthonotus & 92.53 & 66.29 \\
Geryon longypes & 190.24 & 68.82 \\
Micromesistius poutassou & 66.2 & 70.97 \\
Hymenocephalus italicus & 71.36 & 73.08 \\
Sergestes arcticus & 586.32 & 75.12 \\
Munida tenuimana & 68.47 & 76.77 \\
Argyropelecus hemi.. & 28.82 & 78.34 \\
Trachyrincus scabrus & 100.69 & 79.88 \\
Cymbulia peronii & 48.89 & 81.18 \\
Processa canaliculata & 35.02 & 82.47 \\
Solenocera membranacea & 93.4 & 83.57 \\
Plesionika giglioli & 388.66 & 84.6 \\
Notacanthus bonaparte & 23.39 & 85.58 \\
Scyliorhinus canicula & 56.73 & 86.39 \\
Todarodes sagittatus & 10.6 & 87.18 \\
Pagurus alatus & 18.17 & 87.93 \\
Hoplostethus mediterraneus & 33.9 & 88.57 \\
Gennadas elegans & 33.24 & 89.22 \\
Etmopterus spinax & 25.72 & 89.81 \\
Pagellus bogaraveo & 11.68 & 90.4 \\
\hline
\end{tabular}

and salinity similar to that which these variables showed with depth. The abiotic variables of the assemblages thus showed a decrease in mean temperature as depth and salinity increased (Figure 4), as well as along the sampling period, meanwhile diversity indices showed no significant variation along time and latitude.

The abundance-biomass curves plotted for each group showed in each assemblage (Figure 5) a general dominance of abundances over biomasses, which was more evident in the assemblages occupying the shelf. In the case of the slope, there was a superimposition of the two curves at the top, with a slight dominance of biomass at the beginning of the curve in the deepest area.

\section{Discussion}

The results of this study characterized the spring assemblages of fish and large invertebrates along the eastern coasts of the Spanish Mediterranean. Five groups whose distribution was clearly influenced by depth were identified and defined the assemblages of the upper and middle continental shelves and the upper and middle slopes of the study area. This structuring of assemblages based on the influence of depth has been observed on other occasions, mainly in fish taxocoenoses, in the eastern Mediterranean (the northern Aegean Sea [13]; Crete [49]), the central Mediterranean (the Adriatic Sea, [14]; Tuscany, [31, 35, 50] and the Ionian Sea [6]), the Gulf of Lions [15], the Balearic Islands [17, 37], the Catalan coast [20,51], and the Levante coast [22]. However, 
TABLE 4: Species contributing most to dissimilarity between the six groups resulting from the cluster analysis. ABU: mean abundance in the cluster group (n/ $\left.\mathrm{km}^{2}\right) ; \%$ Cum: cumulative percentage of species contribution. Data from MEDITS surveys series $2007-2010$.

\begin{tabular}{|c|c|c|c|c|c|c|c|}
\hline Group & 1 & 2 & & Group & 2 & 3 & \\
\hline Species & $\mathrm{ABU}$ & $\mathrm{ABU}$ & $\%$ Cum & Species & $\mathrm{ABU}$ & $\mathrm{ABU}$ & $\%$ Cum \\
\hline Sardina pilchardus & 592.19 & 7538.3 & 5.02 & Capros aper & 310.28 & 6602.24 & 5.93 \\
\hline Engraulis encrasicolus & 56.65 & 7485.65 & 9.43 & $\begin{array}{l}\text { Micromessistius } \\
\text { poutassou }\end{array}$ & 21.23 & 36083.68 & 11.68 \\
\hline Trachurus trachurus & 2688.24 & 3332.84 & 13.47 & Sardina pilchardus & 7538.3 & 31.91 & 17.12 \\
\hline Spicara flexuosa & 3626.31 & 267.45 & 17.38 & Trachurus trachurus & 3332.84 & 8477.77 & 22.53 \\
\hline Alloteuthis media & 378.79 & 2176.04 & 20.74 & Engraulis encrasicolus & 7485.65 & 338.86 & 27.34 \\
\hline Boops boops & 3348.89 & 862.9 & 23.72 & Merluccius merluccius & 2275.56 & 4300.94 & 30.99 \\
\hline Merluccius merluccius & 994.31 & 2275.56 & 26.49 & Trisopterus minutus & 1201.81 & 2046.07 & 34.47 \\
\hline $\begin{array}{l}\text { Trachurus } \\
\text { mediterraneus }\end{array}$ & 1784.88 & 1037.77 & 29.26 & Alloteuthis media & 2176.04 & 1264.22 & 37.72 \\
\hline Trisopterus minutus & 2041.41 & 1201.81 & 31.93 & Aphia minuta & 2989.04 & 3.46 & 39.97 \\
\hline Mullus barbatus & 1557.57 & 586.49 & 34.45 & $\begin{array}{l}\text { Trachurus } \\
\text { mediterraneus }\end{array}$ & 1037.77 & 16.83 & 42.2 \\
\hline Aphia minuta & 255.74 & 2989.04 & 36.78 & Boops boops & 862.9 & 120.17 & 44.35 \\
\hline Pagellus erythrinus & 1371.72 & 318 & 38.84 & Mullus barbatus & 586.49 & 371.4 & 46.07 \\
\hline Spicara smaris & 3573.98 & 81.39 & 40.8 & Illex coindetii & 504.08 & 334.25 & 47.77 \\
\hline Group & 3 & 4 & & Group & 4 & 5 & \\
\hline Species & $\mathrm{ABU}$ & $\mathrm{ABU}$ & $\%$ Cum & Species & $\mathrm{ABU}$ & $\mathrm{ABU}$ & $\%$ Cum \\
\hline $\begin{array}{l}\text { Micromessistius } \\
\text { poutassou }\end{array}$ & 36083.68 & 8774.87 & 7.56 & Gadiculus argenteus & 10603.1 & 1.14 & 8.35 \\
\hline Gadiculus argenteus & 518.86 & 10603.1 & 14.13 & $\begin{array}{l}\text { Micromessistius } \\
\text { poutassou }\end{array}$ & 8774.87 & 66.2 & 14.73 \\
\hline Trachurus trachurus & 8477.77 & 542.87 & 19.72 & $\begin{array}{l}\text { Plesionika } \\
\text { heterocarpus }\end{array}$ & 3418.14 & 0.84 & 19.44 \\
\hline Capros aper & 6602.24 & 831.78 & 24.43 & $\begin{array}{l}\text { Lampanictus } \\
\text { crocodrilus }\end{array}$ & 184.39 & 1196.54 & 22.6 \\
\hline Merluccius merluccius & 4300.94 & 309.44 & 28.74 & Pasiphaea sivado & 2501.06 & 51.16 & 25.41 \\
\hline $\begin{array}{l}\text { Plesionika } \\
\text { heterocarpus }\end{array}$ & 1207.52 & 3418.14 & 32.67 & Scyliorhinus canicula & 1000.87 & 56.73 & 28.03 \\
\hline Trisopterus minutus & 2046.07 & 154.97 & 35.62 & Aristeus antennatus & 0 & 560.6 & 30.23 \\
\hline Alloteuthis media & 1264.22 & 10.8 & 38.05 & Plesionika martia & 130.91 & 626.62 & 32.4 \\
\hline Phycis blennoides & 39.08 & 1312.92 & 40.27 & Nephrops norvegicus & 528.09 & 391.85 & 34.43 \\
\hline Pasiphaea sivado & 0.75 & 2501.06 & 42.44 & Galeus melastomus & 372.5 & 446.57 & 36.45 \\
\hline Scyliorhinus canicula & 550.15 & 1000.87 & 44.47 & Capros aper & 831.78 & 8.86 & 38.42 \\
\hline $\begin{array}{l}\text { Glossanodon } \\
\text { leioglossus }\end{array}$ & 895.09 & 2614.9 & 46.13 & Phycis blennoides & 1312.92 & 251.77 & 40.38 \\
\hline $\begin{array}{l}\text { Helicolenus } \\
\text { dactylopterus }\end{array}$ & 221.1 & 636.33 & 47.7 & Plesionika giglioli & 401.14 & 388.66 & 42.33 \\
\hline
\end{tabular}

it is often argued that the distribution of marine organisms may respond not only to depth, but also to a combination of depth-related factors such as bottom type, food availability, light intensity, temperature, and pressure [52].

Demersal assemblages are often stable over time $[15,31$, 34,53 ], showing a specific spatial distribution that is closely linked to depth. In our case, results are in concordance with this pattern, due to the lack of significance of variations along the time of the mean values of the diversity indices, and to the clear relationship found between the identified groups and depth (Figure 7). On a western Mediterranean macroscale, three assemblages of demersal fish were previously identified: one in the Alboran Sea, one in the Catalan-Levante area, and another in the Gulf of Lions [15]. This faunal pattern of differentiation between the Gulf of Lions and the CatalanLevante area can be partly explained by the influence, on a mesoscale, of a permanent hydrographic structure [15]. The diminishing trend observed in the average temperature of samples in the study period can be attributed to particular variations and influence of this hydrographic characteristic, rather than other climatic effects. Temperature and salinity showed no significant influence on assemblages definition, 
TABle 5: Average values for the samples of each identified group: Species number $(S)$, species richness (Margalef index) $(D)$, Pielou Evenness $(J)$, and Shannon diversity (Hloge). Data from MEDITS surveys series 2007-2010.

\begin{tabular}{lccccc}
\hline Diversity & Group 1 & Group 2 & Group 3 & Group 4 & Group 5 \\
\hline$S( \pm$ SD $)$ & $46.455(11.859)$ & $37.532(11.486)$ & $37.052(8.434)$ & $42.429(7.746)$ & $37.209(7.405)$ \\
$D( \pm$ SD $)$ & $4.493(1.010)$ & $3.621(1.096)$ & $3.452(0.762)$ & $4.049(0.722)$ & $4.180(0.733)$ \\
$J( \pm$ SD $)$ & $0.637(0.112)$ & $0.566(0.141)$ & $0.459(0.144)$ & $0.519(0.135)$ & $0.644(0.089)$ \\
Hloge $( \pm$ SD $)$ & $2.417(0.435)$ & $2.032(0.548)$ & $1.646(0.523)$ & $1.931(0.491)$ & $2.315(0.345)$ \\
\hline
\end{tabular}

TABLE 6: Correlation matrix between year, depth, temperature, salinity, and latitude of the sample, species number $(S)$, number of individuals $(N)$, species richness (Margalef Index) $(D)$, Pielou evenness $(J)$, and Shannon diversity (Hloge). Asterisks indicate significant results in the Bonferroni test. Data from MEDITS surveys series 2007-2010.

\begin{tabular}{|c|c|c|c|c|c|c|c|c|c|c|}
\hline & Year & Depth & Temperature & Salinity & Latitude & $S$ & $N$ & $D$ & $J$ & Hloge \\
\hline Year & 1 & & & & & & & & & \\
\hline Depth & -0.004 & 1 & & & & & & & & \\
\hline Temperature & $-0.248^{*}$ & $-0.431^{*}$ & 1 & & & & & & & \\
\hline Salinity & -0.179 & $0.845^{*}$ & $-0.482^{*}$ & 1 & & & & & & \\
\hline Latitude & 0.078 & -0.088 & 0.161 & $-0.251^{*}$ & 1 & & & & & \\
\hline$S$ & -0.064 & -0.075 & 0.151 & -0.092 & -0.124 & 1 & & & & \\
\hline$N$ & 0.053 & -0.121 & 0.047 & -0.167 & 0.048 & 0.092 & 1 & & & \\
\hline$D$ & -0.063 & 0.145 & 0.080 & 0.083 & -0.109 & $0.918^{*}$ & -0.097 & 1 & & \\
\hline$J$ & -0.126 & 0.177 & 0.114 & 0.129 & 0.068 & 0.027 & $-0.411^{*}$ & $0.310^{*}$ & 1 & \\
\hline Hloge & -0.141 & 0.150 & 0.139 & 0.099 & 0.031 & $0.285^{*}$ & $-0.377^{*}$ & $0.539^{*}$ & $0.963^{*}$ & 1 \\
\hline
\end{tabular}

but in some species considered stenothermic or stenohaline, such as $A$. antennatus, species that shows a direct relationship with the Levantine Intermediate Water; these variables have been shown to be more important than depth for their biomass distribution [54]. While these abiotic variables have also been shown to contribute to the segregation of species such as $M$. barbatus and $M$. surmuletus with more intensity than depth [55].

It has also been suggested that demersal assemblages are partially linked with sediment type and composition of macrofauna communities [33], although the lack of sediment data in this study prevented us from confirming this. However, the similarity between samples belonging to each group ranged from $30 \%$ to $41 \%$, suggesting that there is some variability of habitats within the depth range of distribution of each assemblage that is responsible for the relative heterogeneity observed in the samples of each group. In general, these similarity indices increase with the mean depth corresponding to each group, a finding that could be related to the existence of more homogeneous conditions in the deep zones and less homogeneous ones in the shelf zone. In fact, there is a relationship between depth and sediment type in the area, so in general sediments of gravels and coarse sands are found in shallower areas of the shelf $w$ and the grain size of the sediments decreases as the distance from the coast increases, with the finest mud in the deeper areas [56-58]. The preponderance of gravel and sand-muddy bottoms on the continental shelf in some areas near river mouths of the study area and of terrigenous mud in off-shore areas (Figure 7) could explain the existence of two different assemblages on the upper shelf (Groups 1 and 2).

The identified assemblages were dominated by fish. This dominance was greatest on the shelf, where cephalopods such as O. vulgaris, A. media, and I. coindetii and crustaceans such as $L$. depurator and D. arrosor were also found. On the upper slope we found a greater number of crustacean species, such as $P$. heterocarpus, $M$. tuberculatus, and $N$. norvegicus and on the middle slope crustaceans made a larger contribution to the structure of the assemblage in both number of species and abundance. In general, the contribution of cartilaginous fish to the assemblages was very low, with the exception of that of S. canicula present in all assemblages, and $G$. melastomus and Etmopterus spinax (Linnaeus, 1758) in the deepest stratum.

Thus, we detected a first assemblage on the upper shelf formed by two subgroups (Groups 1 and 2) distributed on bottoms with a mean depth of between 70 and $72 \mathrm{~m}$, depending on the group. Though the species composition was similar in the two assemblages, the first group had higher abundances of swimming species with a priori lower dependence on substrate, while the second group showed high abundances of burrowing fish Cepola macrophthalma (Linnaeus, 1766), a clearly demersal species living in muddysandy coastal bottoms. Furthermore, the high abundances in the samples of Group 2 of $L$. depurator, a species considered to be an indicator or terrigenous muds $[59,60]$, reinforces the hypothesis of a spatial distribution of the two assemblages found on the upper shelf based on the type of 


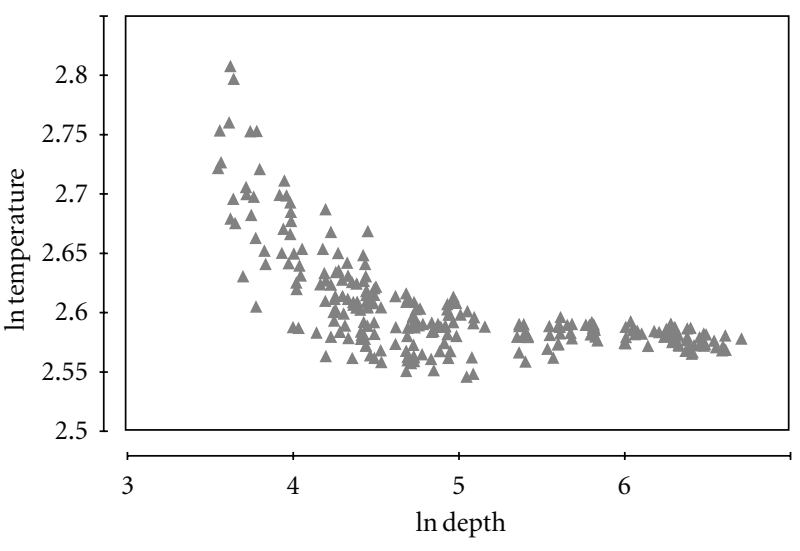

(a)

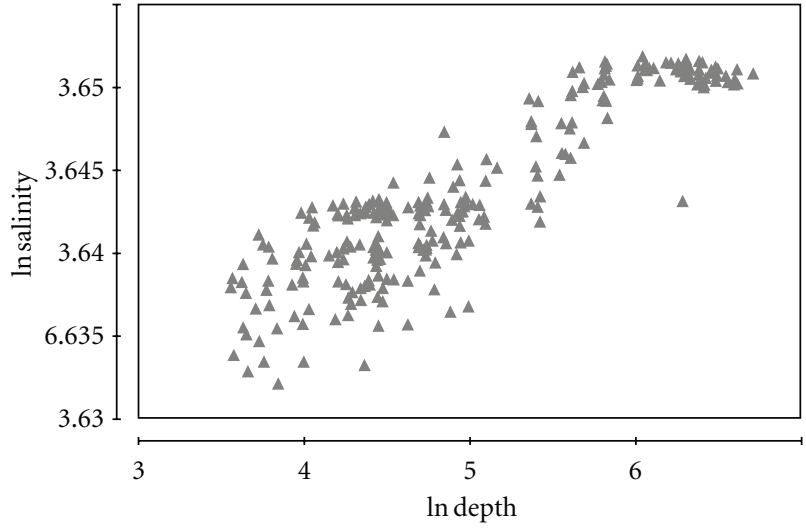

(b)

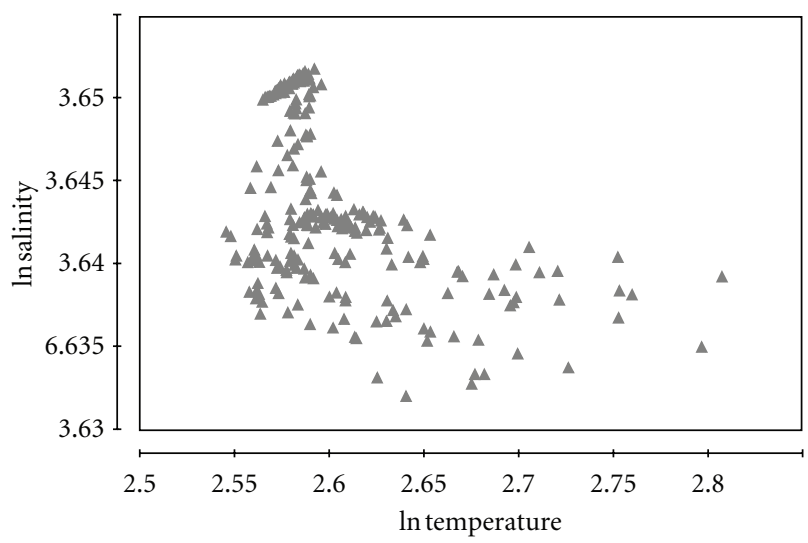

(c)

Figure 3: Relationship between the variables considered: depth-temperature ( $r=-0.619)$; depth-salinity $(r=0.896)$; temperature-salinity $(r=-0.487)$. Data from MEDITS surveys series 2007-2010.

substrate, with Group 1 being mainly distributed in sandmuddy bottom areas characterized by an high sedimentation rate and Group 2 in sediment catchment areas of rivers, in typical terrigenous muddy bottoms located offshore [31] (Figure 7). On the other hand, diversity indices showed higher values in Group 1 than in Group 2. Trawling induces the replacement of vulnerable organisms (e.g., sessile cnidarians, large echinoderms, bivalves) by organisms with a higher ability to withstand the continuous impact of trawling (e.g., starfish, small swimming crabs, polychaetes) [9]. The number of species necessary to represent a $90 \%$ of cumulative contribution was 43 in Group 1 and 28 in Group 2. Furthermore, the abundances in Group 1 of species such as S. canicula, Arnoglossus thori (Kyle, 1913) and S. regalis, some ascidians (Phallusia mamillata (Cuvier, 1815), Ascidia mentula (Müller, 1766), Polycarpa pomaria (Savigny, 1816), Microcosmus vulgaris (Heller, 1877) and some sessile cnidarians such as Alcyonium palmatum (Pallas, 1766), scarce or not present in Group 2, allow us to consider Group 1 as more structured and less disturbed than Group 2, that seems to be more representative of a disturbed terrigenous muddy bottom, covering a wider area (Figure 7).
A depth-related transition of the assemblages was observed from the middle shelf to the upper slope. The middle shelf assemblage was located at a mean depth of $128 \mathrm{~m}$ and showed the lowest mean diversity of the shelf and slope. On a large scale, it was observed that species richness tended to reach maximum values between 80 and $110 \mathrm{~m}$ depth [15]. On a smaller scale, the presence of stable demersal assemblages on the shelf was detected in the Gulf of Lions, organized along a depth gradient with a separation at $80-100 \mathrm{~m}$ depth [61]. In our case, this pattern coincides with that observed in the upper and middle shelf assemblages. The shelf-edge assemblage, located at a mean depth of $170 \mathrm{~m}$, defines a zone characterized by detrital organogenic sediments, very often colonized by Leptometra phalangium (J. Müller, 1841) [62] and influenced by shelf break upwelling in which area of influence the echinoderm Spatangus purpureus (O. F. Müller, 1776) is also found [7]. In our case, these species showed mean depths of occurrence of $112 \mathrm{~m}$ for L. phalangium and $145 \mathrm{~m}$ for S. purpureus.

For deeper assemblages, two depth-differentiated bathyal assemblages separated at around 400-500 $\mathrm{m}$ depth were formerly described [6], confirming that the transition between 


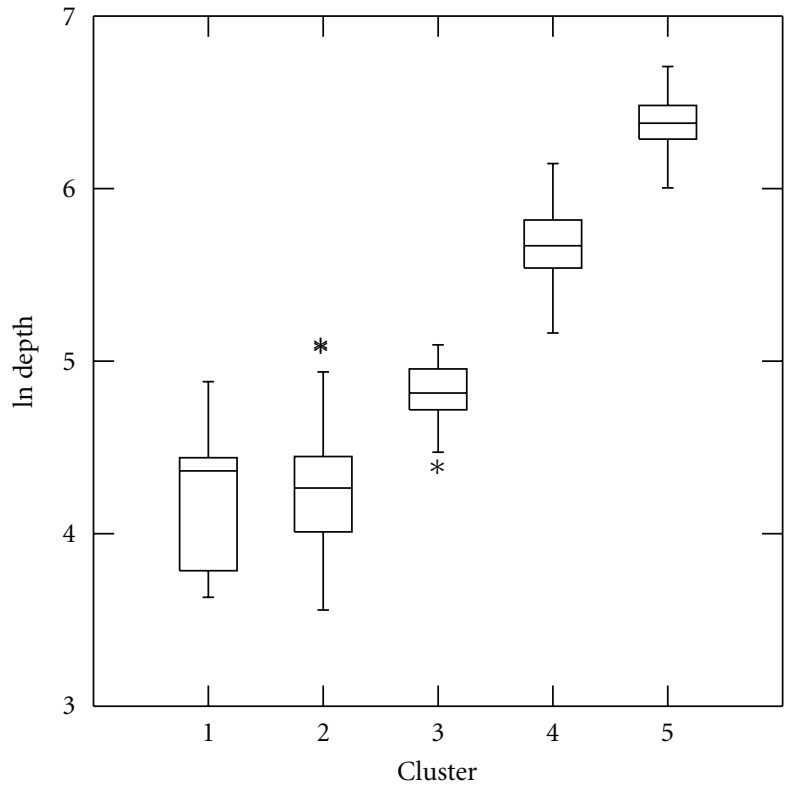

(a)

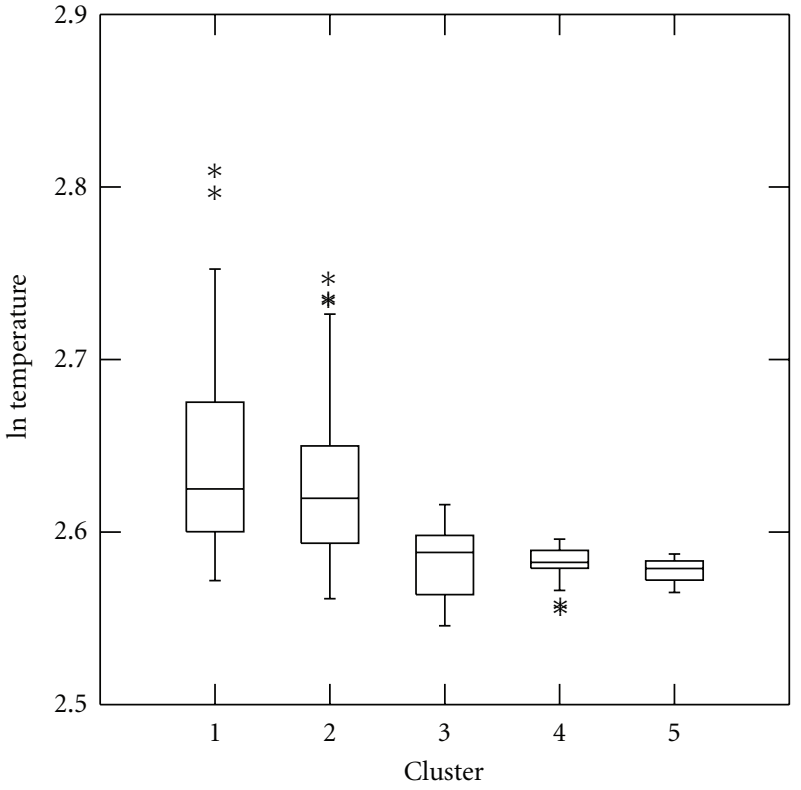

(b)

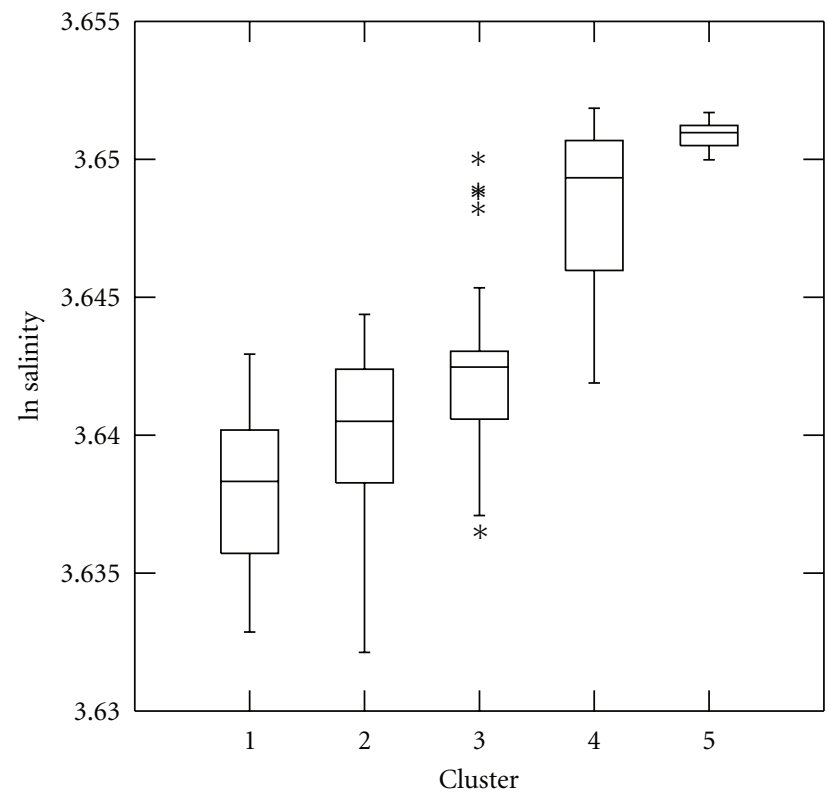

(c)

Figure 4: Box plots of the abiotic variables for each identified group: depth, temperature and salinity. The ends of the lines represent the limits of distribution, the box represents the standard deviation and the horizontal line represents the mean. Clusters 1 and 2 corresponding to upper shelf; Cluster 3 to middle shelf; Cluster 4 to upper slope; Cluster 5 corresponds to middle slope. Data from MEDITS surveys series 2007-2010.

the upper slope and the strictly bathyal fauna is located at $400-500 \mathrm{~m}$ depth $[51,63,64]$. In our case, the two slope assemblages identified had a transition depth located at $436 \mathrm{~m}$, with a mean depth of $298 \mathrm{~m}$ for the upper slope assemblage and of $589 \mathrm{~m}$ for the middle slope assemblage.

In general, the defined assemblages resulted very similar to those described in other Mediterranean areas such as the central Mediterranean [31], the Gulf of Lions [34], or the Catalan coast [20]. The number of defined assemblages varies slightly, from three to six, from one area to another mainly due to the different statistical methods used to identify the different groups. In most similar cases, there is a coincidence into identifying at least four assemblages: upper or coastal shelf, middle shelf, upper slope, and middle slope. Considering species composition a good agreement exists between similar assemblages from the different areas, despite the occurrence differences in species distribution along the Mediterranean. Species such as A. minuta, P. erythrinus, D. 


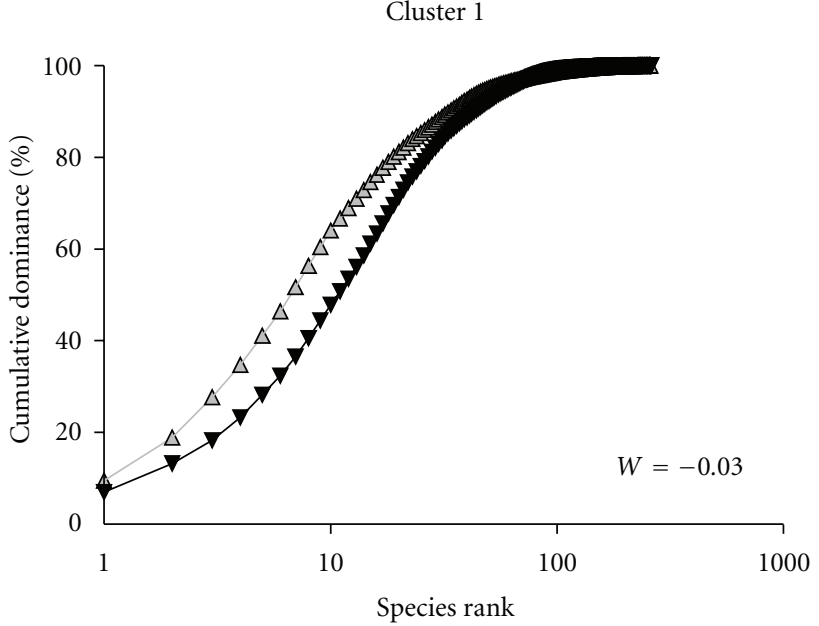

(a)

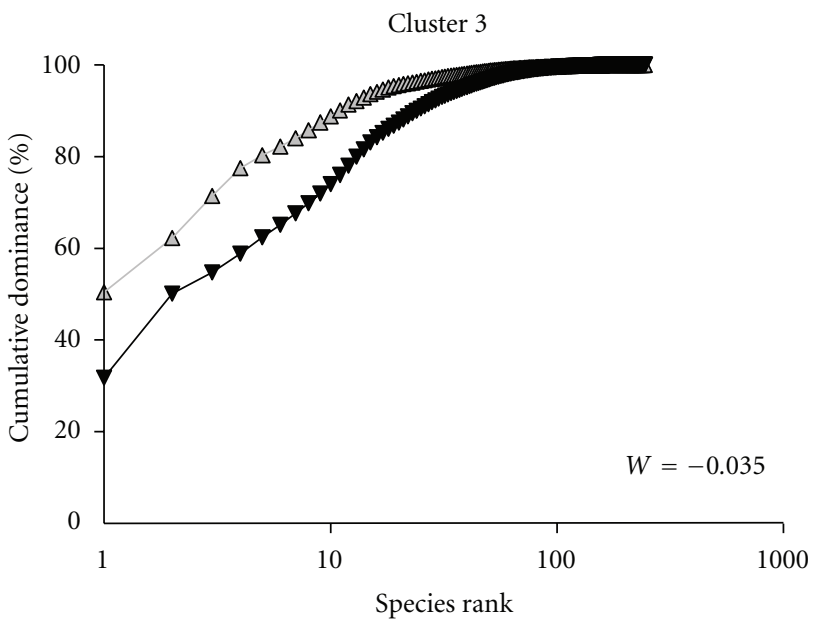

(c)

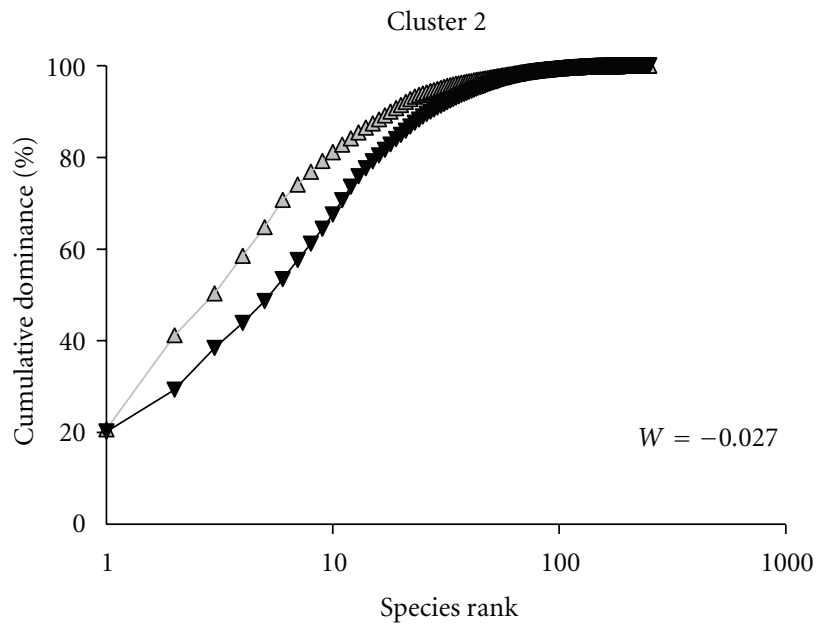

(b)

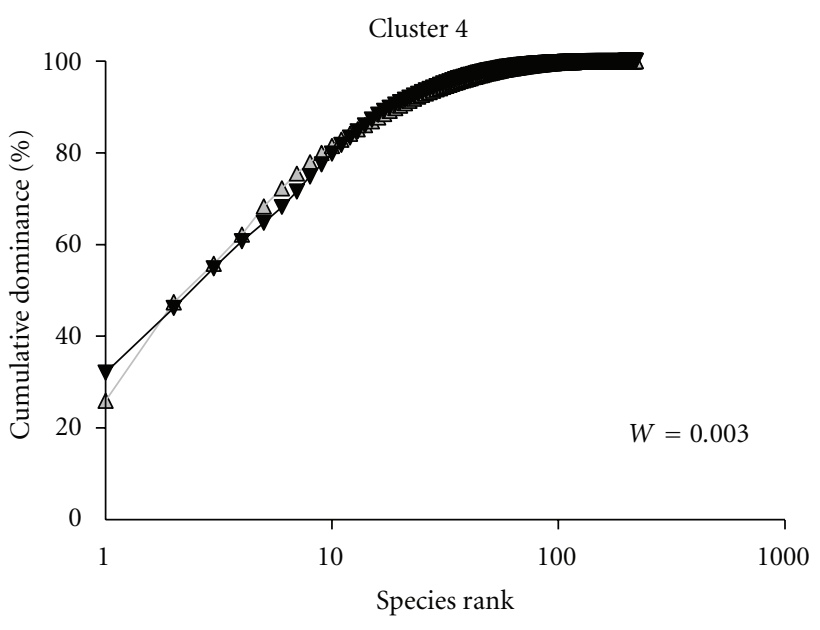

(d)

Figure 5: Abundance-biomass curves for the five identified clusters. Abundances $(\triangle)$; biomasses ( $\mathbf{\nabla})$. Cluster 1 and 2 corresponding to upper shelf; Cluster 3 to middle shelf; Cluster 4 to upper slope; Cluster 5 corresponds to middle slope. Data from MEDITS surveys series 2007-2010.

annularis, S. maena, or B. boops are strongly associated with the Alicante-Catalan Sea region, while species such as Lepidorhombus boscii, Citharus linguatula, Lepidotrigla dieuzeidei, Chelidonichthys (Eutrigla) gurnardus, Buglossidium luteum, Argentina sphyraena, and Solea solea mainly characterized the Gulf of Lions [15].

The abundance-biomass curves generally showed a dominance of species abundances over biomass. This fact, which shows the dominance of the contribution of small individuals of the species, tends to be considered an indicator of the alteration of a specific assemblage and/or community $[9,65]$. The dominance of relatively small organisms is probably an adaptation to the changes brought about by frequent trawling, which involves the elimination of large individuals of slow-growing species. For example, differences between the curves for the heavily exploited Italian waters and the less exploited Albanian waters of the Adriatic were described [14]. This trend was also observed in the abundance-biomass cumulative curves, which demonstrated dominance by small organisms that contributed little to community biomass in the most impacted areas when comparing with areas with no trawl fishing activity in the Catalan coast [9]. We observe a major alteration of assemblages on the upper and middle shelf than on the slope. On the upper slope there was a moderate alteration, whereas on the middle slope the alteration was lesser at the beginning of the curve but reached the same level as the upper slope when a few more species were added.

With regard to biological diversity, the number of species per sample varied between the groups, but showed no significant trend with depth, implying that bathymetry has little influence on the multicomponent structuring of species diversity $[66,67]$. However, in the Gulf of Lions [15], a species richness gradient that decreased from the coast to the upper slope was found. The mean values were moderately high, near, or slightly below the mean value of the range of each index. In general there was a tendency for the mean number of species and diversity indices to decrease from 


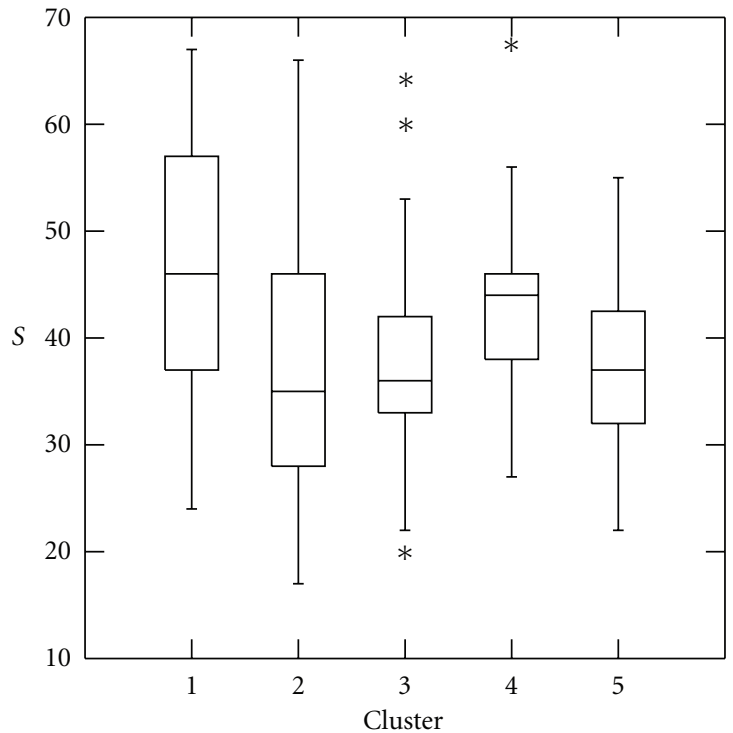

(a)

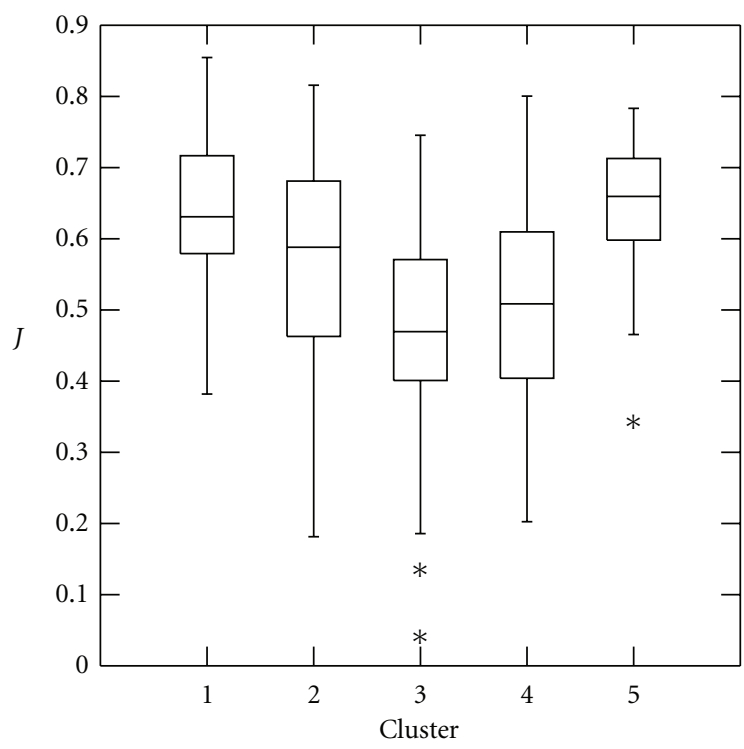

(c)

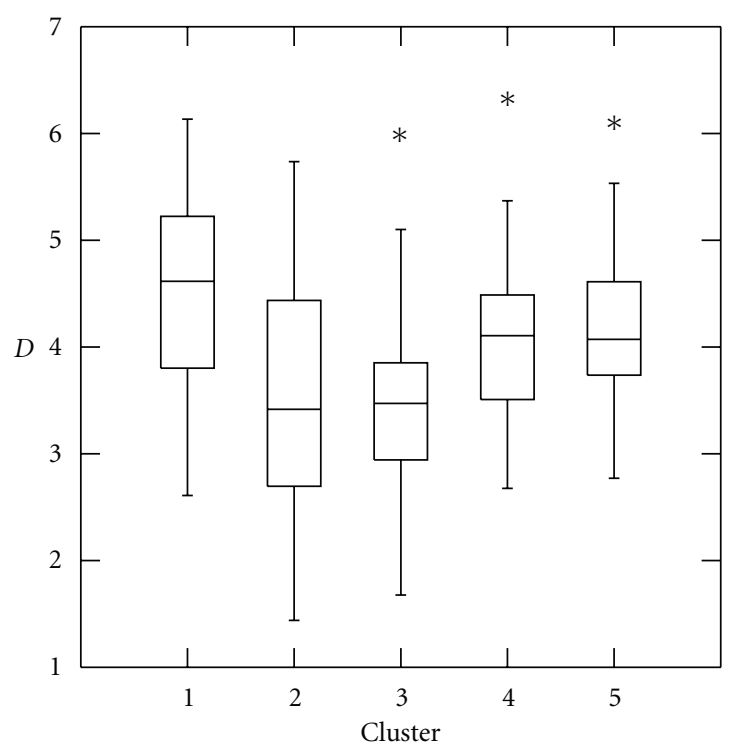

(b)

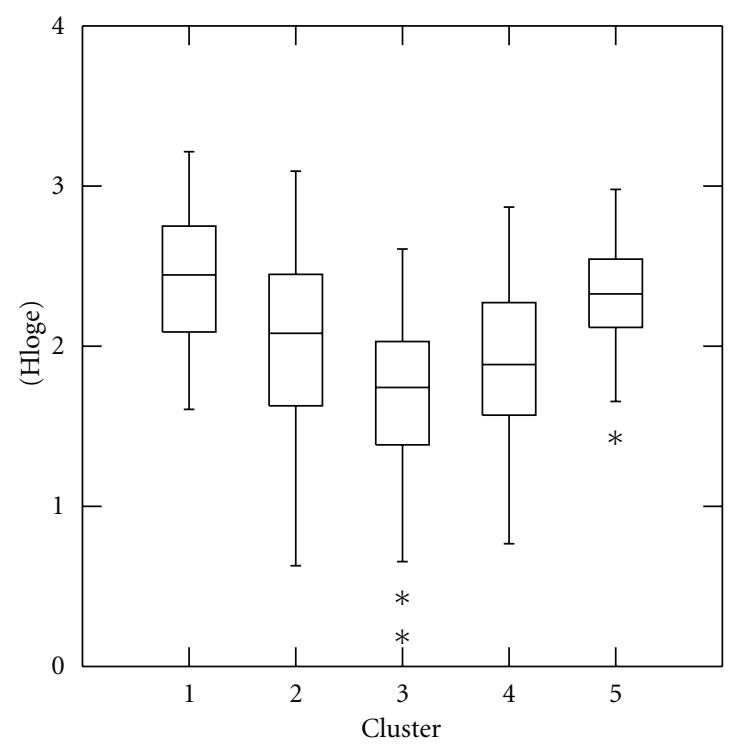

(d)

Figure 6: Box plots of the mean diversity for each identified group (Cluster): species number $(S)$, species richness (Margalef index) ( $D$ ), Pielou Evenness $(J)$, and Shannon diversity (Hloge). The ends of the lines represent the limits of distribution, the box represents the standard deviation box, and the horizontal line represents the mean. Clusters 1 and 2 corresponding to upper shelf; Cluster 3 to middle shelf; Cluster 4 to upper slope; Cluster 5 corresponds to middle slope. Data from MEDITS surveys series 2007-2010.

the upper to the middle shelf and to increase slightly on the upper and middle slope. Overall, the mean values found in the indices can be considered moderately high, showing that the species richness in the western Mediterranean may be higher than that in other areas. On the slope of the Ionian Sea [6] and in Corsica [67] slightly lower mean diversity values were found in assemblages than those reported in this paper. Nevertheless, diversity indices are indifferent to species substitutions which may reflect ecosystem stresses (such as those due to high fishing intensity). In addition, some species, mainly from the slope, exhibit strong variability in its distribution area [34]. In this sense the species composition and structure of the assemblages described in this work will be helpful for future studies to detect changes in its specific composition and/or proportions, as well as to compare with results from other areas.

In conclusion, the existence of these well-defined, depthbased demersal assemblages should be considered in future studies of fisheries assessment because it facilitates ecosystem-based management. The multispecies nature of Mediterranean trawl fisheries and the moderate diversity observed suggest that the state of health of the Spanish Mediterranean is relatively good, probably due to ecosystem resilience based on a large number of interactions among species. However, 


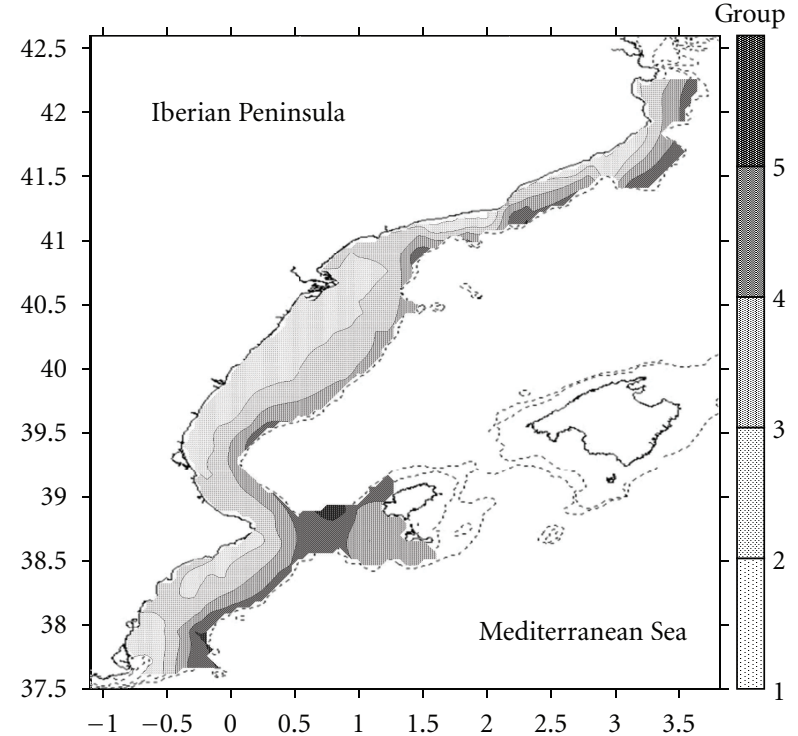

FIGURE 7: Representation of the geographical distribution of the areas occupied by the Cluster identified in the study area. Clusters 1 and 2 corresponding to upper shelf; Cluster 3 to middle shelf; Cluster 4 to upper slope; Cluster 5 corresponds to middle slope. Cumulative data from MEDITS surveys series for the period 20072010.

all the assemblages studied showed signs of alteration, which suggests a persistent impact of fishing on their structure. From the point of view of fisheries management, it is important to monitor, in time and space, the stability or changes of these assemblages impacted by fisheries, because they can be useful for future multispecies management of fisheries.

\section{Acknowledgments}

The authors wish to thank Cristina Bultó and Miguel Vivas for their collaboration in faunal tables and the participants, scientific staff and crew of the MEDITS GSA06 series of surveys, which were cofunded by the EU.

\section{References}

[1] S. Jennings and M. J. Kaiser, "The effects of fishing on marine ecosystems," Advances in Marine Biology, no. 34, pp. 201-352, 1998.

[2] S. J. Hall, The Effects of Fishing on Marine Ecosystems and Communities, Blackwell Science, Oxford, UK, 1999.

[3] R. Goñi, "Ecosystem effects of marine fisheries: an overview," Ocean and Coastal Management, vol. 40, no. 1, pp. 37-64, 1998.

[4] R. Goñi, "Fisheries effects on ecosystems," in Seas at the Millennium, C. Shepherd, Ed., vol. III, pp. 117-133, Elsevier Science, Amsterdam, The Netherlands, 2000.

[5] S. Jennings, S. P. R. Greenstreet, and J. D. Reynolds, "Structural change in an exploited fish community: a consequence of differential fishing effects on species with contrasting life histories," Journal of Animal Ecology, vol. 68, no. 3, pp. 617627, 1999.

[6] G. D'Onghia, F. Mastrototaro, A. Matarrese, C. Y. Politou, and C. Mytilineou, "Biodiversity of the upper slope demersal community in the Eastern Mediterranean: preliminary comparison between two areas with and without trawl fishing," Journal of Northwest Atlantic Fishery Science, vol. 31, pp. 263273,2003

[7] S. De Juan, S. F. Thrush, and M. Demestre, "Functional changes as indicators of trawling disturbance on a benthic community located in a fishing ground (NW Mediterranean Sea)," Marine Ecology Progress Series, vol. 334, pp. 117-129, 2007.

[8] M. García-Rodríguez, J. L. Pérez Gil, J. Peña, and R. Sáez, "Results of a commercial trawl survey on an unexploited continental slope trawl-fishing ground off the Columbretes Islands (Castellón, eastern Iberian Peninsula)," Informes Tecnicos del Instituto Espanol de Oceanografia, no. 187, pp. 1-50, 2007.

[9] S. de Juan, M. Demestre, and P. Sánchez, "Exploring the degree of trawling disturbance by the analysis of benthic communities ranging from a heavily exploited fishing ground to an undisturbed area in the NW Mediterranean," Scientia Marina, vol. 75, no. 3, pp. 507-516, 2011.

[10] F. Biagi, S. De Ranieri, M. Mori, P. Sartor, and M. Sbrana, "Preliminary analysis of demersal fish assemblages in the northern Tyrrhenian Sea," Nova Thalassia, vol. 10, no. 1, pp. 391-398, 1989.

[11] G. D’Onghia, A. Tursi, P. Maiorano, A. Matarrese, and M. Panza, "Demersal fish assemblages from the bathyal grounds of the Ionian Sea (middle-eastern Mediterranean)," Italian Journal of Zoology, vol. 65, pp. 287-292, 1998.

[12] V. Vassilopoulou, C. Papaconstantinou, and P. Bekas, "Demersal fish community patterns in two areas of the Aegean Sea, Greece," Italian Journal of Zoology, vol. 65, pp. 293-297, 1998.

[13] M. Labropoulou and C. Papaconstantinou, "Community structure of deep-sea demersal fish in the North Aegean Sea (northeastern Mediterranean)," Hydrobiologia, vol. 440, pp. 281-296, 2000.

[14] N. Ungaro, G. Marano, R. Marsan, and K. Osmani, "Demersal fish assemblage biodiversity as an index of fishery resources exploitation," Italian Journal of Zoology, vol. 65, pp. 511-516, 1998.

[15] J. C. Gaertner, J. A. Bertrand, L. G. De Sola, J. P. Durbec, E. Ferrandis, and A. Souplet, "Large spatial scale variation of demersal fish assemblage structure on the continental shelf of the NW Mediterranean Sea," Marine Ecology Progress Series, vol. 297, pp. 245-257, 2005.

[16] E. Massutí, O. Reñones, A. Carbonell, and R. Oliver, "Demersal fish communities exploited on the continental shelf and slope off majorca (Balearic Islands, NW Mediterranean)," Vie et Milieu, vol. 46, no. 1, pp. 45-55, 1996.

[17] J. Moranta, C. Stefanescu, E. Massutí, B. Morales-Nin, and D. Lloris, "Fish community structure and depth-related trends on the continental slope of the Balearic Islands (Algerian basin, western Mediterranean)," Marine Ecology Progress Series, vol. 171, pp. 247-259, 1998.

[18] J. Moranta, E. Massutí, and B. Morales-Nin, "Fish catch composition of the deep-sea decapod crustacean fisheries in the Balearic Islands (western Mediterranean)," Fisheries Research, vol. 45, no. 3, pp. 253-264, 2000.

[19] C. Stefanescu, B. Morales-Nin, and E. Massuti, "Fish assemblages on the slope in the Catalan Sea (western Mediterranean): influence of a submarine canyon," Journal of the 
Marine Biological Association of the United Kingdom, vol. 64, no. 3, pp. 499-512, 1994.

[20] M. Demestre, P. Sánchez, and P. Abelló, "Demersal fish assemblages and habitat characteristics on the continental shelf and upper slope of the north-western Mediterranean," Journal of the Marine Biological Association of the United Kingdom, vol. 80, no. 6, pp. 981-988, 2000.

[21] L. Gil De Sola Simarro, "Demersal fishes of Alboran Sea continental shelf, SW Iberian Mediterranean," Boletín del Instituto Español de Oceanografía, vol. 10, no. 1, pp. 63-79, 1994.

[22] A. M. Fernández and M. García Rodríguez, "Demersal fish assemblages from the continental shelf and upper slope trawling grounds off the SE Spain (western Mediterranean)," Rapport Commission Internationale pour l'exploration Scientifique de la Mer Mediterraneé, vol. 37, p. 353, 2004.

[23] C. Stefanescu, D. Lloris, and J. Rucabado, "Deep-sea fish assemblages in the Catalan Sea (western Mediterranean) below a depth of 1000 m," Deep-Sea Research, vol. 40, no. 4, pp. 695-707, 1993.

[24] J. E. Cartes and F. Sarda, "Zonation of deep-sea decapod fauna in the Catalan Sea (Western Mediterranean)," Marine Ecology Progress Series, vol. 94, no. 1, pp. 27-34, 1993.

[25] J. E. Cartes, J. B. Company, and F. Maynou, "Deep-water decapod crustacean communities in the northwestern Mediterranean: influence of submarine canyons and season," Marine Biology, vol. 120, no. 2, pp. 221-230, 1994.

[26] P. Abelló, A. Carbonell, and P. Torres, "Biogeography of epibenthic crustaceans on the shelf and upper slope off the Iberian Peninsula Mediterranean coasts: implications for the establishment of natural management areas," Scientia Marina, vol. 66, no. 2, pp. 183-198, 2002.

[27] E. Massutí and J. Moranta, "Demersal assemblages and depth distribution of elasmobranchs from the continental shelf and slope off the Balearic Islands (western Mediterranean)," ICES Journal of Marine Science, vol. 60, no. 4, pp. 753-766, 2003.

[28] A. Quetglas, A. Carbonell, and P. Sánchez, "Demersal continental shelf and upper slope cephalopod assemblages from the Balearic Sea (north-western Mediterranean). Biological aspects of some deep-sea species," Estuarine, Coastal and Shelf Science, vol. 50, no. 6, pp. 739-749, 2000.

[29] M. González and P. Sánchez, "Cephalopod assemblages caught by trawling along the Iberian Peninsula Mediterranean coast," Scientia Marina, vol. 66, no. 2, pp. 199-208, 2002.

[30] F. Ordines and E. Massutí, "Relationships between macroepibenthic communities and fish on the shelf grounds of the western Mediterranean," Aquatic Conservation, vol. 19, no. 4, pp. 370-383, 2009.

[31] F. Colloca, M. Cardinale, A. Belluscio, and G. Ardizzone, "Pattern of distribution and diversity of demersal assemblages in the central Mediterranean sea," Estuarine, Coastal and Shelf Science, vol. 56, no. 3-4, pp. 469-480, 2003.

[32] M. G. Pennino, J. M. Bellido, D. Conesa, and A. López-Quílez, "Trophic indicators to measure the impact of fishing on an exploited ecosystem," Animal Biodiversity and Conservation, vol. 34, no. 1, pp. 123-131, 2011.

[33] J. C. Gaertner, N. Mazouni, R. Sabatier, and B. Millet, "Spatial structure and habitat associations of demersal assemblages in the Gulf of Lions: a multicompartmental approach," Marine Biology, vol. 135, no. 1, pp. 199-208, 1999.

[34] J. C. Gaertner, J. A. Bertrand, and A. Souplet, "STATISCoA: a methodological solution to assess the spatio-temporal organization of species assemblages. Application to the demersal assemblages of the French Mediterranean Sea," Scientia Marina, vol. 66, no. 2, pp. 221-232, 2002.

[35] F. Biagi, P. Sartor, G. D. Ardizzone, P. Belcari, A. Belluscio, and F. Serena, "Analysis of demersal assemblages off the Tuscany and Latium coasts (north-western Mediterranean)," Scientia Marina, vol. 66, no. 2, pp. 233-242, 2002.

[36] F. Sarda, J. E. Cartes, and J. B. Company, "Spatio-temporal variations in megabenthos abundance in three different habits of the Catalan deep sea (western Mediterranean)," Marine Biology, vol. 120, no. 2, pp. 211-220, 1994.

[37] E. Massutí and O. Renones, "Demersal resource assemblages in the trawl fishing grounds off the Balearic Islands (western Mediterranean)," Scientia Marina, vol. 69, no. 1, pp. 167-181, 2005.

[38] Estadísticas Pesqueras, "Censo de flota pesquera operativa a 31 de Diciembre 2009," Secretaría General Técnica. Subdirección General de Estadística. Ministerio de Medio Ambiente y Medio rural y Marino. N.I.P.O.: 770-10-169-5, 2010.

[39] J. F. Caddy, "Some future perspectives for assessment management of Mediterranean fisheries," Scientia Marina, vol. 57, no. 2-3, pp. 105-119, 1993.

[40] P. Oliver, "Analysis of fluctuations observed in the trawl fleet landings of the Balearic Islands (western Mediterranean)," Scientia Marina, vol. 57, no. 2-3, pp. 219-227, 1993.

[41] P. Martin, P. Sartor, and M. García-Rodríguez, "Comparative analysis of the exploitation strategy of the European hake (Merluccius merluccius), red mullet (Mullus barbatus) and striped red mullet (Mullus surmuletus) in the Western Mediterranean," Journal of Applied Ichthyology, vol. 15, pp. 2428, 1999.

[42] Scientific, Technical and Economic Committee for Fisheries (STECF), Review of Scientific Advice for 2011. Consolidated Advice on Stocks of Interest to the European Community, 2011, JRC62286 EUR 24660 EN ISBN 978-92-79-18926-5 ISSN 1831-9424.

[43] G. Relini, P. Carpenteri, and M. Murenu, Eds., "Manuale di instruzioni Medits," Biologia Marina Mediterranea, vol. 15, no. 2, pp. 1-78, 2008.

[44] J. Bertrand, L. Gil de Sola, C. Papacostantinou, G. Relini, and A. Souplet, "An international bottom trawl survey in the Mediterranean: the MEDITS programme," in Demersal Resources in the Mediterranean, vol. 26 of Proceedings of the Symposium, Pisa, March 18-21, 1998, pp. 76-93, IFREMER, Plouzane, France, 2000, Actes de Colloques.

[45] L. Fiorentini, P. Y. Dremière, I. Leonori, A. Sala, and V. Palumbo, "Efficiency of the bottom trawl used for the Mediterranean international trawl survey (MEDITS)," Aquatic Living Resources, vol. 12, no. 3, pp. 187-205, 1999.

[46] J. E. Cartes, F. Maynou, D. Lloris, L. G. de Sola, and M. Garcia, "Influence of trawl type on the composition and diversity of deep benthopelagic fish and decapod assemblages off the Catalan coasts (western Mediterranean)," Scientia Marina, vol. 73, no. 4, pp. 725-737, 2009.

[47] J. A. Bertrand, L. G. De Sola, C. Papaconstantinou, G. Relini, and A. Souplet, "The general specifications of the MEDITS surveys," Scientia Marina, vol. 66, no. 2, pp. 9-17, 2002.

[48] K. R. Clarke and R. N. Gorley, PRIMER v5: User Manual/Tutorial, PRIMER-E, Plymouth, UK, 2001.

[49] A. Kallianiotis, K. Sophronidis, P. Vidoris, and A. Tselepides, "Demersal fish and megafaunal assemblages on the Cretan continental shelf and slope (NE Mediterranean): seasonal 
variation in species density, biomass and diversity," Progress in Oceanography, vol. 46, no. 2-4, pp. 429-455, 2000.

[50] E. Fanelli, F. Colloca, and G. Ardizzone, "Decapod crustacean assemblages off the West coast of central Italy (western Mediterranean)," Scientia Marina, vol. 71, no. 1, pp. 19-28, 2007.

[51] P. Abelló, F. J. Valladares, and A. Castellón, "Analysis of the structure of decapod crustacean assemblages off the Catalan coast (North-West Mediterranean)," Marine Biology, vol. 98, no. 1 , pp. 39-49, 1988.

[52] J. E. Cartes, F. Maynou, J. Moranta, E. Massutí, D. Lloris, and B. Morales-Nin, "Patterns of bathymetric distribution among deep-sea fauna at local spatial scale: comparison of mainland vs. insular areas," Progress in Oceanography, vol. 60, no. 1, pp. 29-45, 2004.

[53] M. Labropoulou and C. Papaconstantinou, "Community structure and diversity of demersal fish assemblages: the role of fishery," Scientia Marina, vol. 68, no. 1, pp. 215-226, 2004.

[54] M. García Rodríguez, A. Fernández, and A. Esteban, "Influence of abiotic factors in the biomass of deep water shrimps, $P$. longirostris and A. antennatus, off Catalano-Levantine Mediterranean coast of Spain," Rapport Commission Internationale pour l'exploration Scientifique de la Mer Mediterraneé, vol. 39, p. 524, 2010.

[55] M. García Rodríguez, A. Fernández, and A. Esteban, "Biomass response to environmental factors in two congeneric species of Mullus, M. barbatus and M. surmuletus, off CatalanoLevantine Mediterranean coast of Spain: a preliminary approach," Animal Biodiversity and Conservation, vol. 34, no. 1, pp. 113-122, 2011.

[56] A. Maldonado, "Evolución de las cuencas mediterráneas y reconstrucción detallada de la Paleoceanografía Cenozoica," in Mediterráneo Occidental, R. Margalef, Ed., Ediciones Omega, Barcelona, Spain, 1989.

[57] A. Maldonado and M. Canals, "El margen continental surbalear: un modelo deposicional reciente sobre un margen de tipo pasivo," Acta Geológica Hispánica, vol. 17, no. 4, pp. 241254, 1982.

[58] J. Rey and T. Medialdea, Los Sedimentos Cuaternarios Superficiales del Margen Continental Español, vol. 3, Instituto Español de Oceanografía, 1989.

[59] R. Minervini, N. Giannotta, and L. Falciai, "A preliminary report on the Decapod crustaceans in the estuarine area of the Tiber," Quaderni del Laboratorio di Tecnologia della Pesca, vol. 3, pp. 305-318, 1982.

[60] P. Abelló, "Pautes de distribució de les espècies de la família Portunidae (Crustacea: Brachyura) als fons de substrat tou de la Mediterrània nord-occidental," Butlletí de la Institució Catalana d'Història Natural, vol. 61, pp. 59-68, 1993.

[61] J. C. Gaertner, D. Chessel, and J. Bertrand, "Stability of spatial structures of demersal assemblages: a multitable approach," Aquatic Living Resources, vol. 11, no. 2, pp. 75-85, 1998.

[62] F. Colloca, P. Carpentieri, E. Balestri, and G. D. Ardizzone, "A critical habitat for Mediterranean fish resources: shelfbreak areas with Leptometra phalangium (Echinodermata: Crinoidea)," Marine Biology, vol. 145, no. 6, pp. 1129-1142, 2004.

[63] J. M. Pérès and J. Picard, "Nouveau manuel de bionomie benthique de la mer Méditerranée," Recueil des Travaux de la Station Marine d'Endoume, vol. 31, pp. 5-137, 1964.

[64] M. Mura and A. Cau, "Community structure of the decapod crustaceans in the middle bathyal zone of the Sardinian Channel," Crustaceana, vol. 67, no. 3, pp. 259-266, 1994.
[65] K. R. Clarke and R. M. Warwick, Change in Marine Communities: An Approach to Statistical Analysis and Interpretation, Plymouth Marine Laboratory, Plymouth, UK, 1994.

[66] B. Mérigot, J. A. Bertrand, N. Mazouni, C. Manté, J. P. Durbec, and J. C. Gaertner, "A multi-component analysis of species diversity of groundfish assemblages on the continental shelf of the Gulf of Lions (north-western Mediterranean Sea)," Estuarine, Coastal and Shelf Science, vol. 73, no. 1-2, pp. 123136, 2007.

[67] B. Mérigot, J. A. Bertrand, J. C. Gaertner, J. P. Durbec, N. Mazouni, and C. Manté, "The multi-component structuration of the species diversity of groundfish assemblages of the east coast of Corsica (Mediterranean Sea): variation according to the bathymetric strata," Fisheries Research, vol. 88, no. 1-3, pp. 120-132, 2007. 

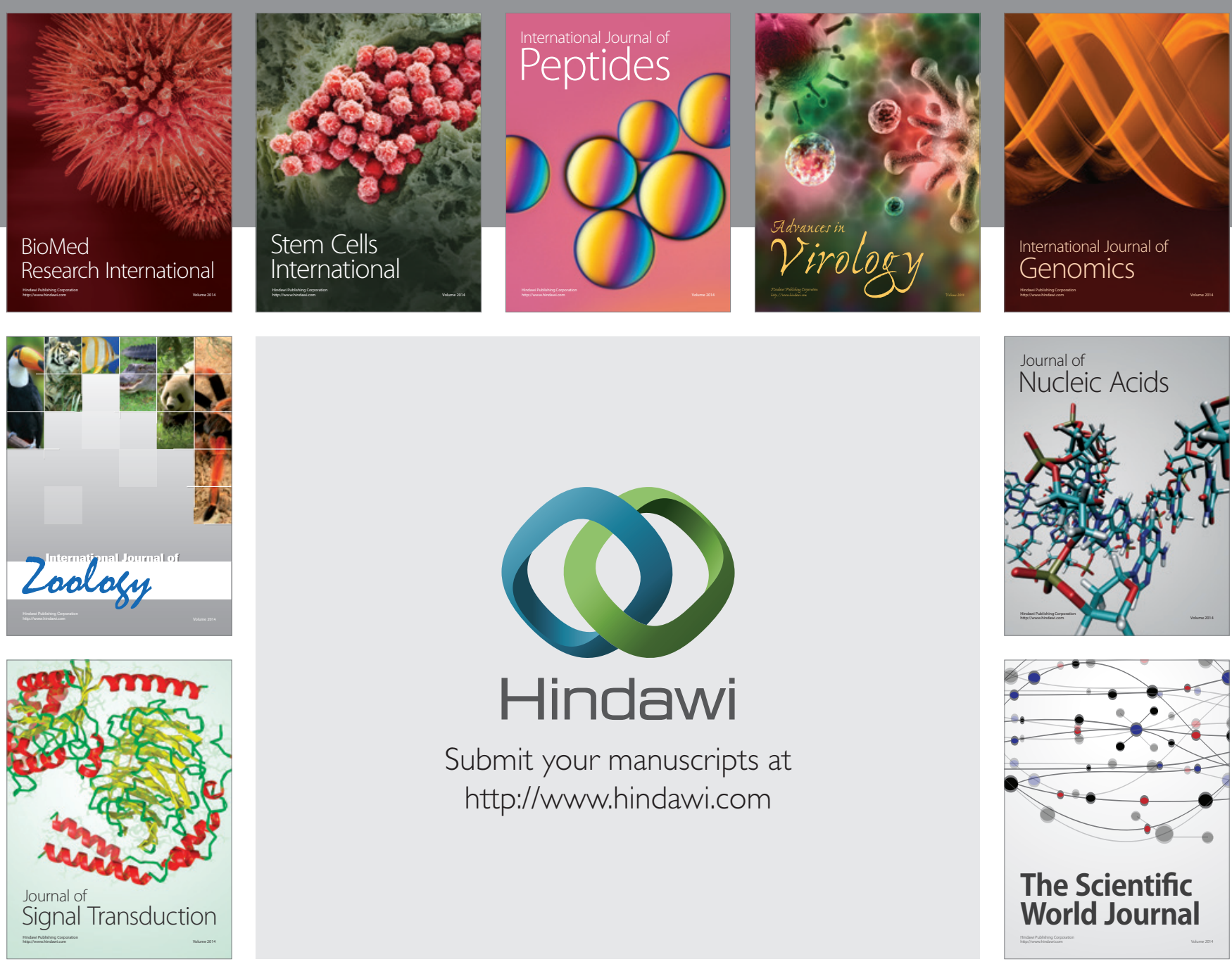

Submit your manuscripts at

http://www.hindawi.com
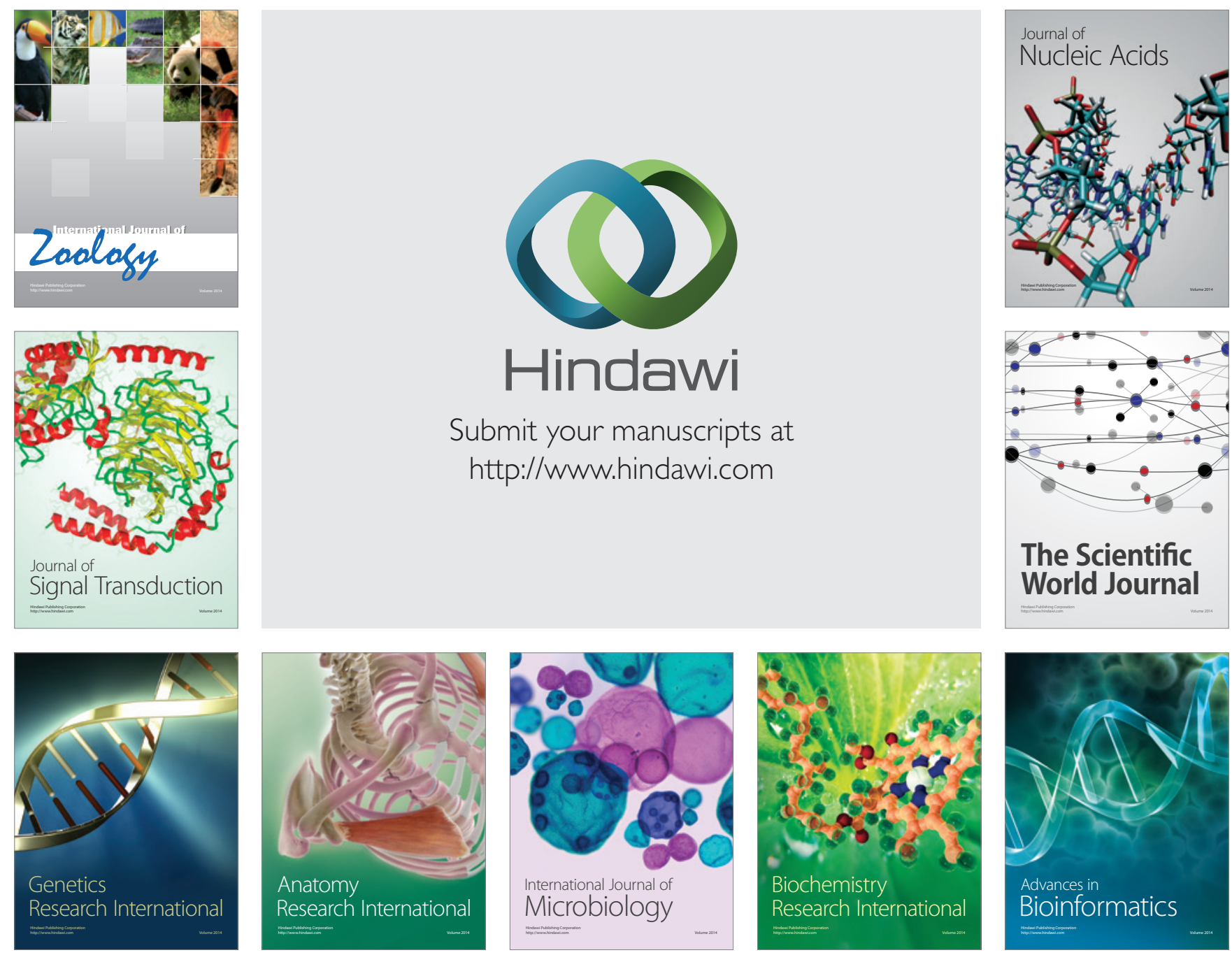

The Scientific World Journal
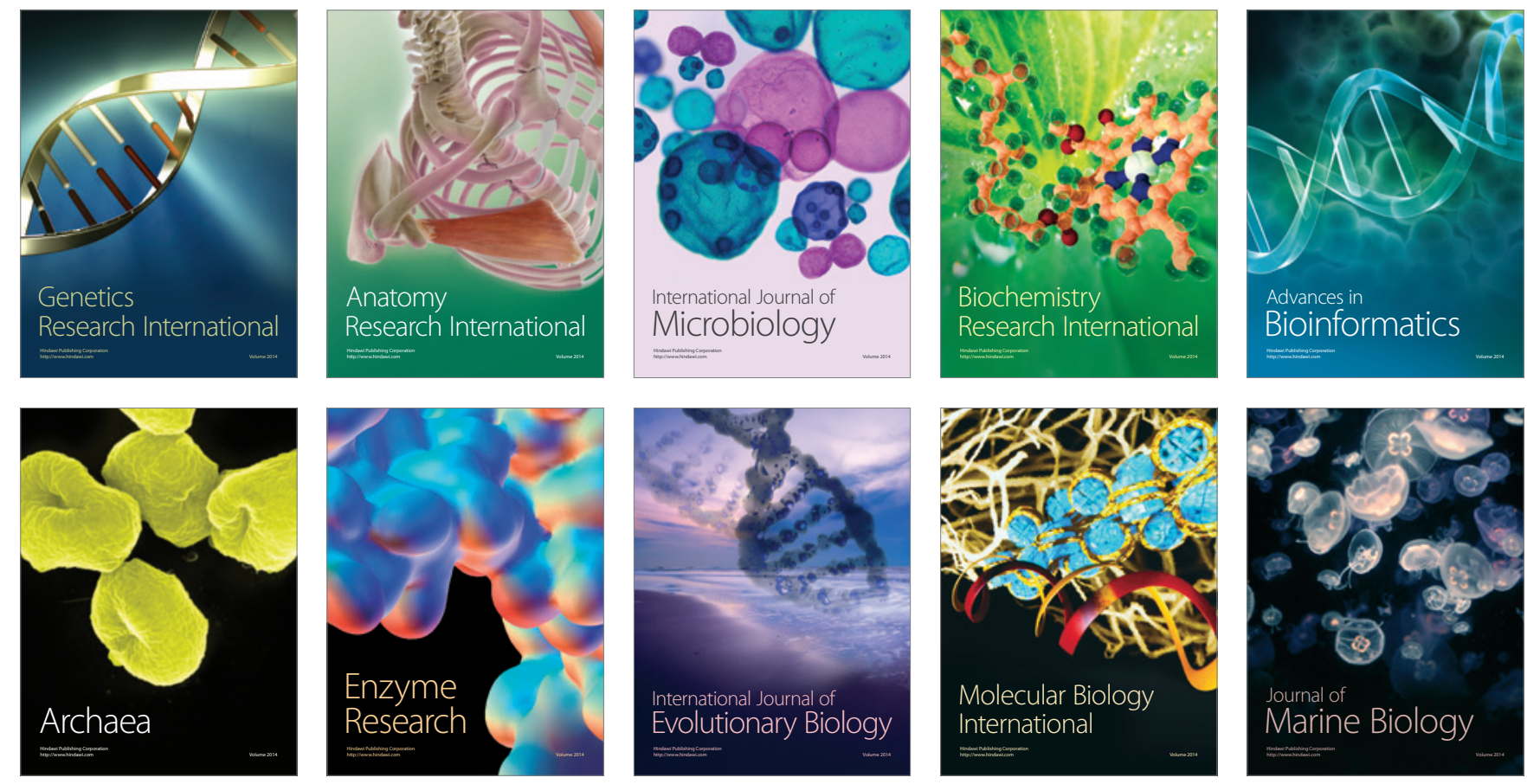